\title{
PRIS I PLIKTIG TILBUD OM KJøP AV AKSJER
}

Kandidatnummer: 546

Veileder: Arne Tjaum

Leveringsfrist: 25.11 .07

Til sammen 17.894 ord 



\section{INNHOLDSFORTEGNELSE}

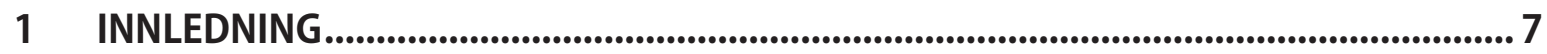

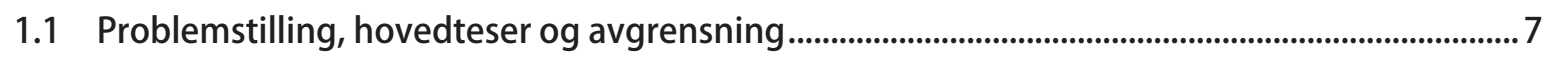

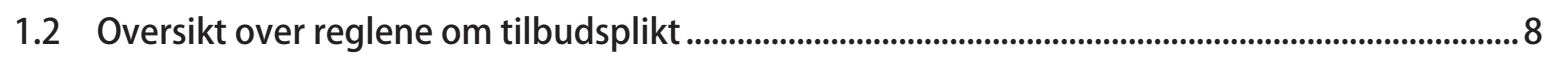

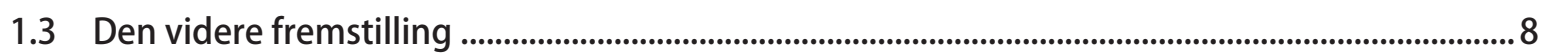

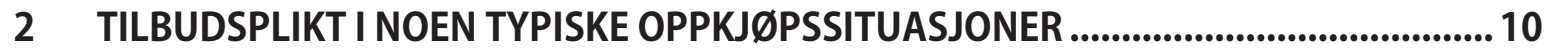

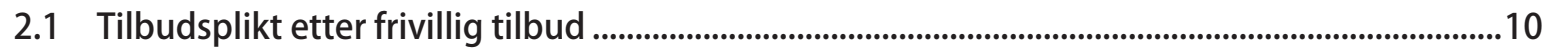

2.2 Tilbudsplikt uten forutgående frivillig tilbud .....................................................................................10

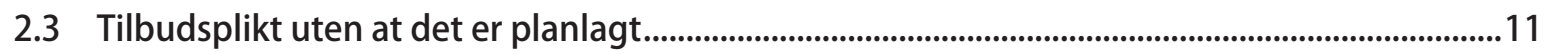

3 LEGISLATIVE HENSYN BAK REGLENE OM TILBUDSPRIS............................................. 12

3.1 Beskyttelse av minoritetsaksjeeiere .......................................................................................12

3.2 Likebehandling av aksjeeiere ............................................................................................................... 12

4 HVEM SOM MÅ HA AVTALT ELLER BETALT VEDERLAGET .......................................... 13

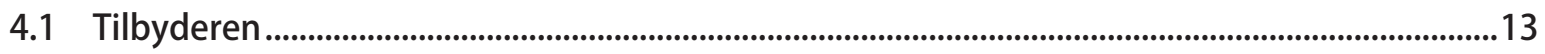

4.1.1 Må tilbyderen være debitor for vederlaget? ......................................................................................................13

4.1.2 Tilbyderen ved indirekte erverv ……………....................................................................................................

4.1.3 Tilbyderen ved konsolidering ..............................................................................................................................

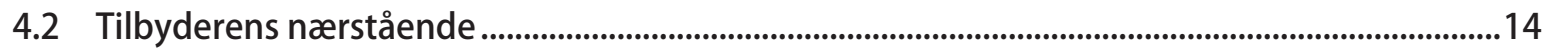

4.2.1 Hovedregelen ....................................................................................................................................... 14

4.2.2 Vederlag fra nærstående avtalt eller betalt etter utløsning av tilbudsplikt...............................................15

4.2.3 Vederlag fra nærstående for aksjer som ikke er omfattet av samarbeid .....................................................15

4.2.4 Vederlag avtalt eller betalt av en tidligere nærstående............................................................................... 16

5 NÅR VEDERLAGET MÅ VAERE AVTALT ELLER BETALT ................................................ 17

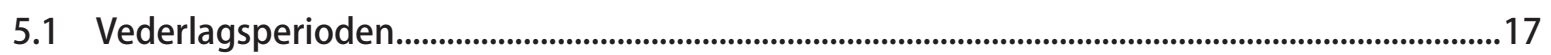

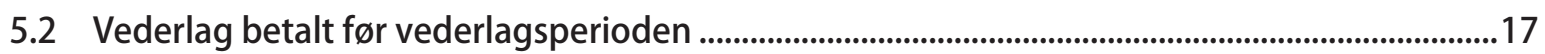

5.2.1 Vederlag ved erverv av eierandel nær tilbudspliktgrensen ................................................................................ 17

5.2.2 Vederlag der tilbyderen blir eier i vederlagsperioden....................................................................................... 17

5.3 Vederlag avtalt eller betalt i vederlagsperioden ...........................................................................17

5.3.1 Vederlag avtalt eller betalt etter utløsning av tilbudsplikt ........................................................................17

5.3.2 Vederlag der tilbyderen ikke blir eier i vederlagsperioden ................................................................................. 18

5.3.3 Vederlag i overlappende vederlagsperioder (gjentatt tilbudsplikt) ................................................................ 18

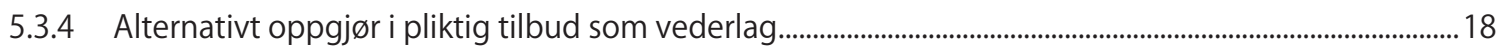

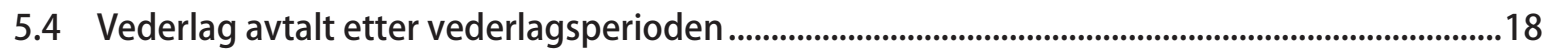


6.1 Avtalealternativet.............................................................................................................................................................2

6.1.1 Opsjoner. Vederlag avtalt ved inngåelse eller innløsning? ...........................................................................2

6.1.2 Betingede avtaler. Vederlag avtalt ved aksept eller inntreden av betingelser?..........................................21

6.1.3 Frivillige tilbud. Vederlag avtalt ved den enkelte aksept eller inntreden av betingelser?.....................21

6.1.4 Vederlag etter ugyldige avtaler (nulliteter) .............................................................................................22

6.1.5 Vederlag etter avtaler som er falt bort........................................................................................................................2

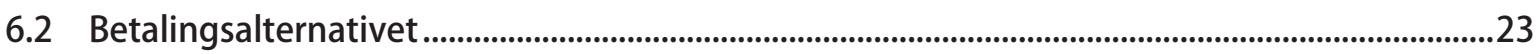

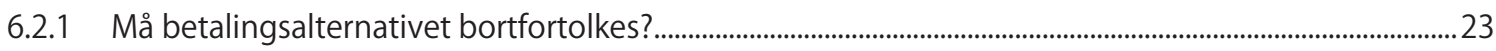

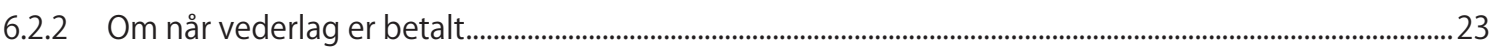

7 GENERELT OM VERDSETTELSEN AV VEDERLAG ...................................................... 24

7.1 Lovens regler om verdsettelsen er ufravikelige ....................................................................................24

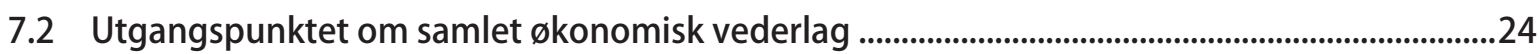

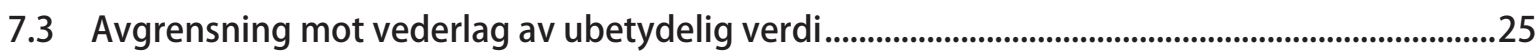

7.4 Avgrensning mot vederlag for tilleggsytelser .......................................................................25

8 SENTRALE VERDSETTELSESPRINSIPPER .............................................................. 26

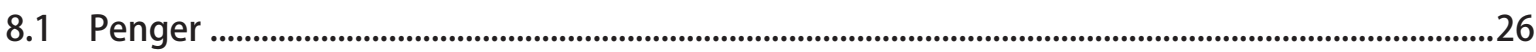

8.1.1 Vederlag og oppgjør i ulik valuta.......................................................................................................................2

8.1.2 Betalingsutsettelse. Deponering av pengevederlag ……………....................................................................2

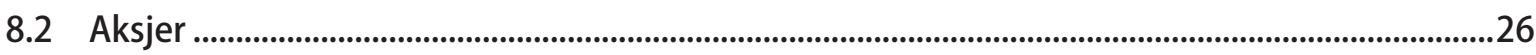

8.2.1 Notert kurs eller virkelig verdi? .....................................................................................................................2

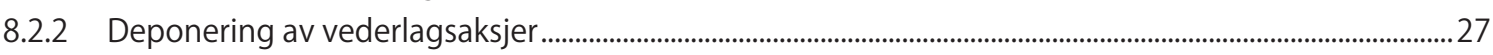

8.2.3 Vederlagsaksjer notert i utlandet....................................................................................................................

8.2.4 Tegningsretter knyttet til vederlagsaksjer ........................................................................................................2

8.2.5 Salgsopsjoner knyttet til vederlagsaksjer ............................................................................................................2

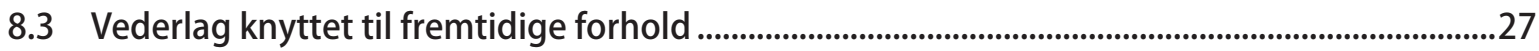

8.3.1 Alle vederlag er betinget av en underliggende avtale ................................................................................2

8.3.2 En del av vederlaget kan være spesielt betinget.............................................................................................2

8.3.3 Vederlag knyttet til fremtidig markedskurs ........................................................................................................ 28

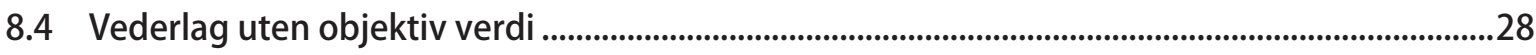

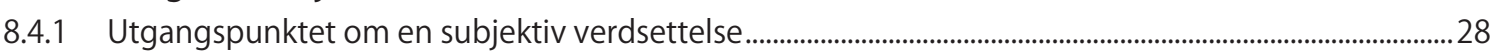

8.4.2 Unntaksvis må verdsettelsen bero på en konkret vurdering ..........................................................................2

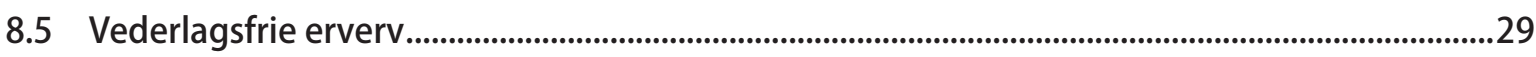

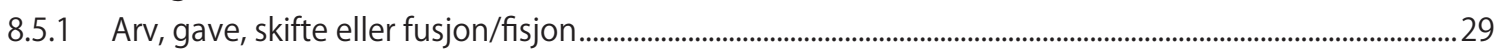

8.5.2 Erverv der vederlaget er betalt før vederlagsperioden ..................................................................................2 
9.1 Hovedregelen om en verdsettelse ved avtale- eller betalingstidspunktet ..................................30

9.2 Særlig om verdsettelsestidspunktet for vederlag etter frivillige tilbud ........................................30

9.3 Vederlagsperioder for vederlag særlig utsatt for verdisvingninger...............................................31

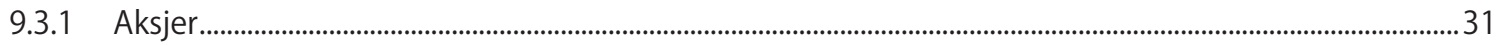

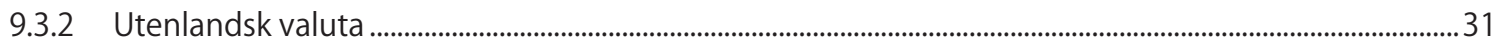

10 OM VEDERLAGSENDRINGER KAN FÅ BETYDNING FOR PRISEN.................................. 32

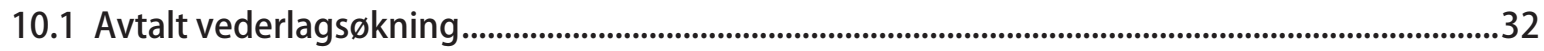

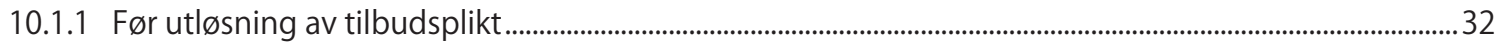

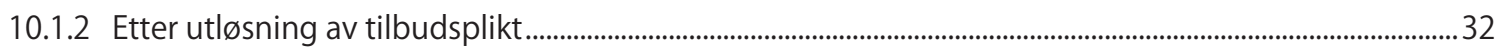

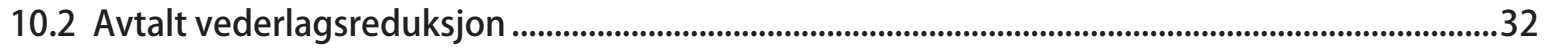

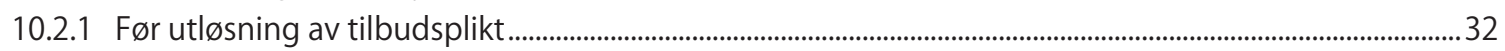

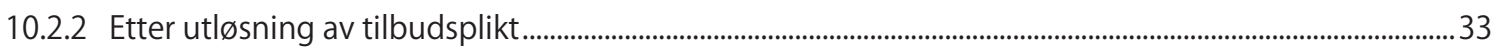

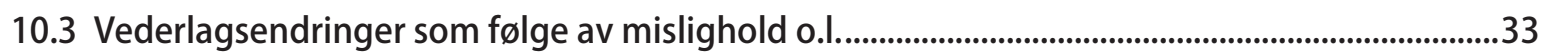

11 AVGRENSNINGER VED KJØP AV TILLEGGSYTELSER ............................................. 35

11.1 Avgrensning av eiendomsrett til aksjer og tilleggsytelser............................................................35

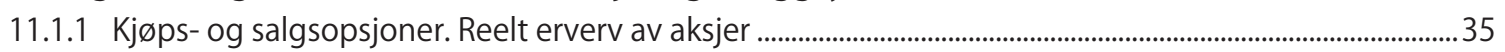

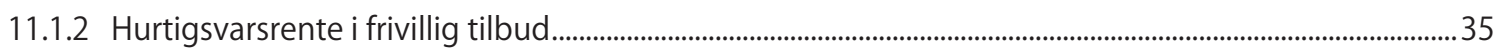

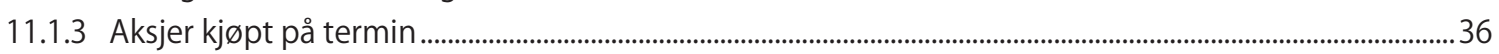

11.2 Avgrensning av vederlag for aksjer og tilleggsytelser .................................................................36

11.2.1 Positiv avgrensning av vederlag for aksjer .........................................................................................................

11.2.2 Negativ avgrensning mot vederlag for tilleggsytelser.......................................................................................

12 PRIS VED FLERE AKSJEKLASSER OG UNOTERTE AKSJER ............................................. 38

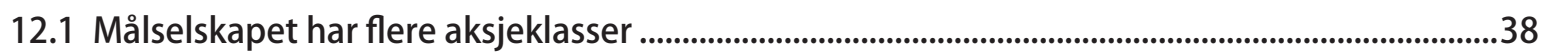

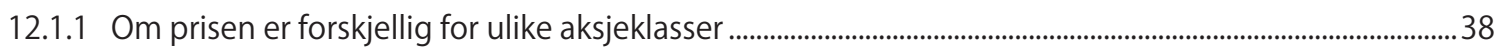

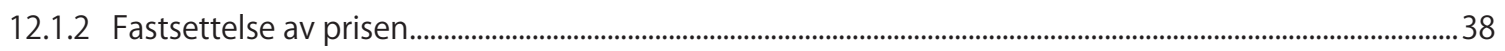

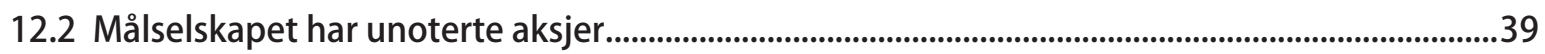

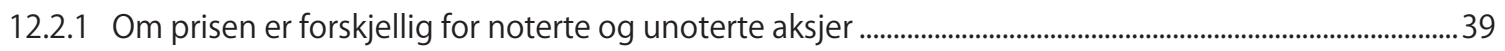

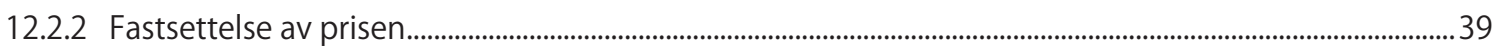

13 PRIS VED ETTERFøLGENDE ENDRINGER I KAPITAL OG PÅLYDENDE ......................... 40

13.1 Om kapitalendringer m.v. kan føre til lavere tilbudspris ...........................................................40

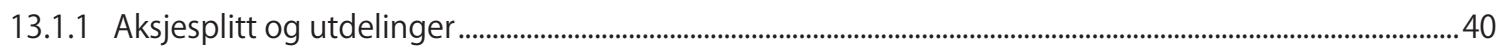

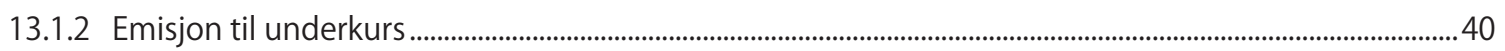

13.2 Om kapitalendringer m.v. kan føre til høyere tilbudspris ..........................................................41 


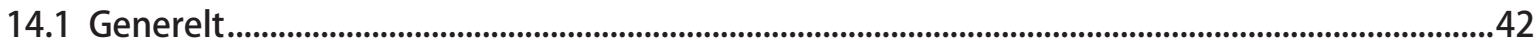

14.1.1 Behovet for en utvidelse av tilbudspliktreglene........................................................................................42

14.1.2 Virkeområdet etter forskriften .......................................................................................................................... 42

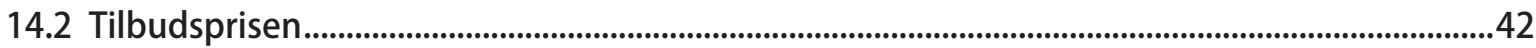

14.2.1 Hvem som må ha avtalt eller betalt vederlaget...............................................................................................42

14.2.2 Avgrensning av vederlaget som kan få betydning for tilbudsprisen............................................................43

14.2.3 Opsjoner. Innløsningspris avtalt ved inngåelse eller innløsning? ..................................................................43

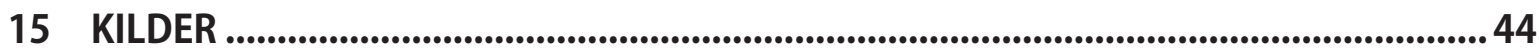

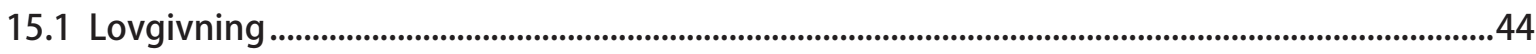

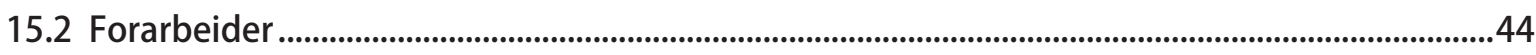

15.3 Vedtak og uttalelser..........................................................................................................................44

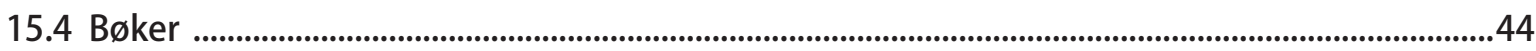

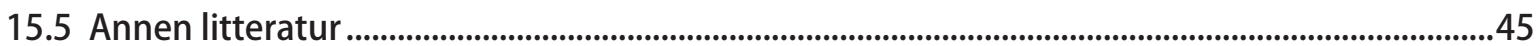




\subsection{Problemstilling, hovedteser og avgrensning}

Reglene om tilbudsplikt innebærer i korte trekk at den som erverver en bestemt andel av de stemmeberettigede aksjene i et notert selskap, blir forpliktet til å fremsette tilbud om kjøp av de øvrige aksjene i selskapet. Emnet for denne avhandlingen er hvilken pris erververen må tilby for aksjene. ${ }^{1}$

Utløsning av tilbudsplikt er oftest del av et planlagt oppkjøp med sikte på 100 prosent eierskap eller minst faktisk kontroll med selskapets generalforsamling. Undersøkelser har vist at selskaper som er blitt kjøpt opp gjennomgående er mer effektive og har høyere produktivitetsvekst enn gjennomsnittet for bedrifter i samme bransje. ${ }^{2}$ Den nye eieren kan få til effektiviseringer ved f.eks. reorganisering, rasjonalisering av drift eller bedret styring og kontroll. Dermed kan oppkjøp også være samfunnsøkonomisk lønnsomme. Oppkjøp kan også være lønnsomme for aksjeeierne i målselskapet, men kan i stedet påføre dem økonomisk tap og annen ulempe. For å gi disse et særskilt vern i oppkjøpssituasjoner, ble det i 1989 innført lovregler om tilbudsplikt i Norge.

For at et oppkjøp skal bli gjennomført, må en potensiell oppkjøper kunne vurdere lønnsomheten ved det mulige oppkjøpet. På kostnadssiden vil kjøpesummen, herunder prisen i pliktig tilbud (tilbudsprisen), stå sentralt. Tilvarende vil tilbudsprisen kunne ha betydning for den avkastningen aksjeeierne i målselskapet oppnår på sine investeringer. Bl.a. av disse grunner er det av stor viktighet med utpreget entydige og klare regler om tilbudsprisen. Slik er imidlertid ikke reglene etter mitt syn. Lovgivningsteknikken er ikke optimal, forarbeidene er kortfattede, domstolspraksis er det lite av, og reglene er ikke grundig analysert i juridisk litteratur.

Når reglene ikke har gitt grunnlag for domstolspraksis, må dette henge sammen med at oppkjøperne gjerne ikke har tid til å vente særlig lenge på en avklaring om tilbudsprisen. De ser seg formodentlig bedre tjent med å godta den tilbakemeldingen eller det vedtak de får fra tilbudsmyndigheten som skal godkjenne prisen. Ettersom tilbudsmyndigheten, som er et privat allmennaksjeselskap med forvaltningsmyndighet, oftest har siste ord om tilbudsprisen i praksis, er et interessant underliggende perspektiv ved denne avhandlingen forholdet mellom tilbudsmyndighetens faktiske og domstolenes antatte rettskildebruk. Forsiktig antydet legger muligens tilbudsmyndigheten jevnt over noe mindre vekt på lovens ordlyd, samt mer vekt på interessene til aksjeeierne i målselskapet på bekostning av oppkjøperne enn hva domstolene antakeligvis ville ha gjort. ${ }^{3}$

De sentrale kommersielle interessene bak reglene om tilbudsplikt og ved den nærmere fortolkningen er altså knyttet til aksjeeierne i målselskapet og oppkjøperne. Men reglene er en del av et omfattende regelverk for verdipapirmarkedet og må ses i sammenheng med dette. Det totale regelverket skal ta hensyn til en rekke interesser av stor økonomisk verdi knyttet til alle aktørene i markedet, herunder markedsplassene (børsene), mellommennene/rådgiverne (verdipapirforetakene), de noterte selskapene og investorene (ikke-profesjonelle og ulike typer av profesjonelle).

Gjeldende lovgivning oppstiller to ulike regler for fastsettelse av tilbudsprisen. Her behandles bare regelen om en tilbudspris lik det høyeste vederlag tilbyderen har avtalt eller betalt i en oppkjøpssituasjon, og ikke den andre regelen om en tilbudspris lik markedskurs når tilbudsplikten inntrer. Begrunnelsen for ikke å behandle markedskursregelen er dels at den har et nokså begrenset virkeområde, ${ }^{4}$ og dels at en beregning av markedskurs i første rekke kan reise spørsmål av økonomisk og ikke juridisk art. 


\subsection{Oversikt over reglene om tilbudsplikt}

Reglene om tilbudsplikt fremgår av lov om verdipapirhandel av 19. juni 1997 nr. 79 (vphl. 1997) kapittel 4. Ny lov om verdipapirhandel ble vedtatt 29. juni 2007 med tilbudspliktregler i kapittel 6, som dels er en videreføring av reglene i vphl. 1997 og dels en gjennomføring av EUs direktiv 2004/25/ EF om overtakelsestilbud (direktivet). Kapittel 6 trer i kraft 1. januar 2008. I avhandlingen bygger jeg likevel på den nye loven, og referanser til "verdipapirhandelloven" og "vphl." er til denne.

Reglene om tilbudsplikt gjelder for aksjeeiere i norske allmennaksjeselskaper som er noterte på norsk regulert marked (noterte selskaper), jf. vphl. $\mathbb{S}$ 6-1(1) første pktm. "Regulert marked" er definert i børsloven $\mathbb{3} 3(1)$. Det er for tiden to regulerte markeder for aksjer i Norge: Oslo Børs og Oslo Axess.

Utgangspunktet er at tilbudsplikt inntrer for den (tilbyderen $)^{5}$ som gjennom erverv blir eier av aksjer som representerer mer enn 1/3 av stemmene i et notert selskap (målselskapet), jf. vphl. $\$$ 6-1(1) første pktm. Gjentatt tilbudsplikt inntrer ved mer enn 40 og 50 prosent, jf. $\$ 6-6(1)$. Loven har regler om at også aksjene til såkalte nærstående skal regnes med ved beregningen av eierandel (konsolidering), jf. $\$$ 6-5. Det vil bli gitt forskrifter om at erverv av rettigheter og andre interesser knyttet til aksjer kan utløse tilbudsplikt, jf. $\$ 6-1(4) .^{6}$

Tilbudsplikten kan bortfalle dersom det foretas salg av den del av aksjene som overstiger tilbudspliktgrensen innen fire uker etter at tilbudsplikten inntrådte (nedsalg), jf. vphl. $\mathbb{S}$ 6-1(1) annet pktm. og 6-6(3).

Et tilbud skal omfatte alle selskapets aksjer, herunder aksjer med begrenset eller uten stemmevekt, jf. vphl. $\$ 6-10(2)$. Det kan ikke gjøres betinget, jf. $\$ 6-10(3)$. Oppgjør i henhold til tilbudet skal skje i penger, jf. $\$$ 6-10(6) første pktm.

Hovedregelen om tilbudspris er at den skal være minst like høy som det høyeste vederlag tilbyderen har betalt eller avtalt i perioden seks måneder før tilbudsplikten inntrådte, jf. vphl. $\mathbb{\$} 6-10(4)$ første pktm. Har tilbyderen etter at tilbudsplikten inntrådte og før utløpet av tilbudsperioden betalt eller avtalt høyere vederlag enn tilbudsprisen, skal nytt tilbud anses fremsatt med en tilbudspris som svarer til det høyere vederlag, jf. $\$ 6-10(5)$ første pktm.

Det er flere unntak fra hovedregelen som innebærer at tilbudsprisen (minsteprisen) er lavere enn det høyeste vederlag. Andre forhold kan tilsi at tilbudsprisen må være høyere.

Tilbyderen skal utarbeide et tilbudsdokument bl.a. med angivelse av tilbudsprisen og hvilken metode som er brukt for å fastsette den, jf. vphl. \$6-13 første og andre ledd nr. 5. Tilbudet og tilbudsdokumentet skal godkjennes av tilbudsmyndigheten før tilbudet fremsettes eller offentliggjøres, jf. $\mathbb{6}$ 6-14(1). Tilbudsmyndigheten er det regulerte marked hvor aksjene i målselskapet er notert, jf. 6-4(1). Vedtak fra tilbudsmyndigheten om å godkjenne eller nekte å godkjenne tilbudsprisen, kan påklages til Børsklagenemnden, jf. børsloven $\mathbb{\$} 41$. Tilbudsmyndigheten og Børsklagenemnden kan omgjøre sine vedtak etter forvaltningsloven $\mathbb{3} 35$. Nemndens vedtak kan bringes inn for ordinære domstoler.

\subsection{Den videre fremstilling}

I punkt 2 blir det gjort rede for tilbudsplikt i noen typiske oppkjøpssituasjoner, d.v.s. den faktiske virkelighet som reglene om tilbudspris er knyttet til, og som det blir vist til i en del drøftelser. I punkt 3 blir de legislative hensyn bak reglene om tilbudspris behandlet. I punkt 4 til 11 blir det gjort rede for hovedregelen, d.v.s. for hvem som må ha avtalt det vederlaget som kan få betydning for tilbudsprisen,

$5 \quad$ Erververen blir kalt "oppkjøperen" før utløsning av tilbudsplikt.

$6 \quad$ Oslo Børs (2007). 
når vederlaget må være avtalt, og hvordan vederlaget skal verdsettes. I punkt 12 og 13 behandles enkelte forhold som kan tilsi at tilbudsprisen (minsteprisen) er lavere eller høyere enn etter hovedregelen. I punkt 14 blir det gjort rede for enkelte sider ved reglene om tilbudspris ved erverv av rettigheter og andre interesser knyttet til aksjer. 


\subsection{Tilbudsplikt etter frivillig tilbud}

I mange tilfeller er en oppkjøper ute etter 100 prosent eierskap. Det dreier seg som regel om en industriell oppkjøper som ønsker integrasjon med målselskapet, og enkelte ganger om et såkalt private equityfond som kjøper opp selskaper som er svakt drevet, tar selskapene av børs, restrukturerer dem, for så å selge eller børsnotere dem igjen. Et viktig ledd i slike oppkjøp er fremsettelse av tilbud om kjøp eller annen overtakelse av alle aksjene eller alle aksjene med stemmerett i målselskapet (frivillig tilbud). Tilbudsprisen vil være basert på oppkjøperens antakelse om hvor mye som skal til for å få kjøpt det antall aksjer han ønsker. Han får åpenbart ikke tak i aksjer til under markedskurs eller særlig mange til markedskurs. Skal han ha forhåpninger om en betydelig akseptgrad, må prisen ligge over markedskurs, d.v.s. være inkludert en overkurs (kontrollpremie). Som regel setter oppkjøperen vilkår i tilbudet, typisk om at han skal bli eier av en viss andel av aksjene; ofte 90 prosent slik at han kan erverve resten av aksjene ved tvangsoverføring, jf. allmennaksjeloven $\mathbb{S} 4-25$. Hvis disse vilkårene blir oppfylt eller frafalt, og oppkjøperen da blir eier av mer enn $1 / 3$ av de stemmeberettigede aksjene i målselskapet, inntrer tilbudsplikten. ${ }^{7}$ Et gjennomført pliktig tilbud ender som regel med tvangsoverføring eller 100 prosent eierskap og strykning av målselskapet fra børs.

Ofte fremsetter oppkjøperen tilbudet før han eier noen aksjer eller rettigheter til aksjer i målselskapet. Andre ganger kjøper han på forhånd aksjer eller rettigheter som tilsvarer mer enn 10 prosent (typisk 10.1 prosent). Med kontroll over en slik eierandel kan oppkjøperen hindre tvangsoverføring, slik at målselskapet blir et mindre attraktivt oppkjøpsobjekt for andre som er ute etter 100 prosent. Dermed reduseres sannsynligheten for konkurrerende tilbud. Forhåndskjøpene er foretatt utenfor regulert marked gjerne fra større aksjeeierer.

\subsection{Tilbudsplikt uten forutgående frivillig tilbud}

Tilbudsplikt kan inntre uten at oppkjøperen først har fremsatt frivillig tilbud. I så fall inntrer som regel plikten etter at oppkjøperen utenfor regulert marked har kjøpt mer enn 1/3 av aksjene over en nokså kort periode, gjerne få dager (her kalt en bloc-kjøp). Kjøpet kan gjelde én enkelt kontrollpost eller alternativt flere poster som samlet gir kontroll. Et eksempel på et en bloc-kjøp er Rambera's kjøp av 39,2 prosent i Aker Yards som ble gjennomført nå i oktober nærmest på en ettermiddag. ${ }^{8}$ Oppkjøperen får naturligvis ikke kjøpt en kontrollerende aksjepost på kort tid uten at han betaler en kontrollpremie. Rambera betalte en (høy) kontrollpremie på kr 27 pr. aksje i Aker Yards, d.v.s. rundt 39 prosent mer enn aksjekursen før oppkjøpet ble kjent i markedet.

Unntaksvis inntrer tilbudsplikt etter at oppkjøperen gradvis har kjøpt seg opp til mer enn $1 / 3$ over en lengre periode i og/eller utenfor marked (gradvis kjøp). Kjøpet kan skje kontinuerlig frem til oppkjøperen overtrer tilbudspliktgrensen. Men det kan også tenkes at han har kjøpt seg nær grensen, og deretter venter i seks måneder før han kjøper den siste lille posten som gjør at han krysser grensen. Ved kjøp i regulert marked blir det ikke betalt noen kontrollpremie, bare markedskurs. Et gjennomført pliktig tilbud etter en bloc-kjøp og gradvise kjøp ender som regel ikke med tvangsoverføring eller 100 prosent eierskap, fordi tilbudsprisen ofte vil være uakseptabel lav.

\footnotetext{
7 Muligens er det slik at et vilkår om konkurransetilsynets godkjenning av ervervet ikke trenger å være oppfylt eller frafalt for at tilbudsplikt skal inntre, jf. Oslo Børs (2007) s. 19-20.

8 Børsmelding 23.10.07. Oppkjøpet utløste riktignok ikke tilbudsplikt etter dagens regler som krever en eierandel på mer enn 40 prosent, jf. vphl. 1997 § 4-1 første ledd.
} 


\subsection{Tilbudsplikt uten at det er planlagt}

I alle de angitte oppkjøpssituasjonene inntrer tilbudsplikt planlagt. Tilbudsplikt kan imidlertid inntre uten at det er planlagt, f.eks. ved nærståendes kjøp av aksjer, eller ved misforståelse/feiltolking av reglene. En beslektet situasjon er der tilbudsplikt er planlagt ut fra en uriktig forutsetning, f.eks. om en bestemt tilbudspris. I Eastern Drilling-saken planla Seadrill tilbudsplikt ut fra den forutsetning at tilbudsprisen skulle beregnes med utgangspunkt i kr 92 pr. aksje, mens Børsen mente prisen skulle være kr 135. ${ }^{9}$ I slike situasjoner vil tilbyderen normalt benytte seg av sin nedsalgsrett. Men nedsalg kan være utelukket, f.eks. fordi fristen er oversittet. Ifølge Børsklagenemnden var Seadrills nedsalgsrett gått tapt fordi selskapet, før det ga melding om at det ville selge seg ned, hadde fremsatt et pliktig tilbud og dermed bundet seg både kontrakts- og verdipapirrettslig. ${ }^{10}$ 
I forarbeidene er det lite å finne om hensyn bak selve tilbudsprisen. Her blir det derfor tatt utgangspunkt i de legislative hensyn bak tilbudsplikt generelt for å se om disse også kan underbygge en bestemt tilbudspris. Disse hensynene er beskyttelse av minoritetsaksjeeiere og likebehandling av aksjeeiere.

\subsection{Beskyttelse av minoritetsaksjeeiere}

Hensynet til beskyttelse av minoritetsaksjeeiere tilsier at "disse ikke skal lide økonomisk tap som følge av overtakelsen, og skal gis en mulighet til å trekke seg ut av selskapet til en akseptabel pris i form av tilbud om overtakelse av aksjer som fremsettes av oppkjøper." ${ }^{11}$ Det dreier seg her om overtakelse av kontroll, d.v.s. stemmeflertall i generalforsamling som i praksis gir kontroll med valg av styret og dermed i realiteten selskapets drift. Reell kontroll i noterte selskaper vil en aksjeeier ofte ha ved mer enn $1 / 3$ av stemmene, fordi minst $1 / 3$ av stemmene enten ikke blir benyttet (aksjeeiere møter ikke opp) eller kan bli benyttet (f.eks forvalterregistrerte aksjer).

Minoritetsaksjeeierne har lidt et "økonomisk tap" som følge av kontrollovertakelsen, dersom, og i den utstrekning, aksjenes verdi rett før overtakelsen ble kjent i markedet var høyere enn aksjenes verdi rett etter overtakelsen. Verdien kan falle ved en overtakelse fordi investorene nedjusterer sine resultatestimater knyttet til selskapet, eller fordi aksjenes likviditet svekkes ved at en stor del av dem kommer i besittelse av én aksjeeier. En tilbudspris lik aksjenes verdi rett før kontrollovertakelsen ble kjent i markedet vil forhindre at minoritetsaksjeeierne lider økonomisk tap. ${ }^{12}$

Nå er ikke en slik tilbudspris gjort til et alternativ etter loven. Likevel er ikke denne tilbudsprisen, eller andre som eventuelt kan utledes av hensynet til minoritetsbeskyttelse etter en nærmere analyse, bare av teoretisk interesse. For det kan tenkes tilfeller der verken vphl. $\mathbb{6} 6-10(4)$ første eller annet pktm kan komme til anvendelse. Et eksempel kan være der tilbudsplikt er utløst etter vederlagsfrie erverv (se punkt 8.5). I slike tilfeller må en tilbudspris bygge på legislative og andre reelle hensyn. ${ }^{13}$

\subsection{Likebehandling av aksjeeiere}

Hensynet til likebehandling av aksjeeiere henger sammen med at en oppkjøper i en overtakelsessituasjon kan være "villig til å betale en overkurs for aksjer i selskapet for å skaffe seg kontroll. De aksjeeierne som selger til overkurs, vil motta en situasjonsbestemt fordel som de øvrige aksjeeierne ikke får. Hensyn til likebehandling tilsier at også øvrige aksjeeiere bør ha rett til å bli løst ut av selskapet til en tilsvarende premie. Dette vil sikre aksjeeierne en pris for aksjene som gir dem en del i kontrollpremien som oppkjøper betaler for sin posisjon i målselskapet." ${ }^{14}$ Likebehandling er et bærende hensyn etter direktivet (jf. art 3 nr.1 bokstav a), City Code (jf. general principles nr 1) og de svenske takeover-reglene (jf. punkt II.10). ${ }^{15}$

\footnotetext{
11 Ot. prp. nr. 34 (2006-2007) s. 359.

12 Dersom kursfallet også er forårsaket av omstendigheter som ikke står i sammenheng med overtakelsen, f.eks. endringer i oljeprisen, må naturligvis verdien av disse komme til fradrag i en eventuell ulovfestet tilbudspris.

13 Se f.eks. Oslo Børs (2006) s. 83 flg., AMN 1999:6 og 2003:32.

14 Ot. prp. nr. 34 (2006-2007) s. 359. Med "selgerne" menes i avhandlingen selgerne av kontrollposten.

15 Om City Code og de svenske takeover-reglene, se punkt 15.5 .
} 


\subsection{Tilbyderen}

For at et vederlag skal kunne få betydning for tilbudsprisen, må det være avtalt eller betalt av "tilbyderen," jf. vphl. \$ 6-10 fjerde og femte ledd. Med "tilbyderen" menes den som plikter å gi tilbud, det vil normalt si den som gjennom erverv blir eier av mer enn 1/3, 40 eller 50 prosent av stemmene, jf. $\mathbb{S} 6-1(1)$ og $6-6(1)$.

\subsubsection{Må tilbyderen være debitor for vederlaget?}

Det er nærliggende å forstå vederlag "tilbyderen [...] har avtalt" som at han må være debitor for vederlaget. En slik forståelse vil imidlertid åpne for omgåelser av reglene ved en splitting av eier- og debitorposisjonen, d.v.s. slik at tilbyderen skal eie aksjene, mens tredjemann skal være debitor. ${ }^{16}$ Meningen er naturligvis ikke at tilbyderen må være debitor, men at vederlaget må være avtalt for aksjer som han skal eie.

\subsubsection{Tilbyderen ved indirekte erverv}

Ifølge vphl. $\mathbb{S}$ 6-1 andre ledd nr. 1 regnes som erverv etter første ledd også erverv av aksjer som representerer mer enn 50 prosent av stemmene i et selskap hvis vesentligste virksomhet består $\mathrm{i}$ å eie aksjer i målselskapet (indirekte erverv). Et eksempel gir omstruktureringen av Actinor Shipping ASA i 2001, der Inship AS ervervet 50 prosent av aksjene i Paal Wilson \& Co. AS som fra før eide over 90 prosent av aksjene i Actinor. ${ }^{17}$ Ved slike og andre indirekte erverv (jf. $\$$ 6-1 andre ledd nr. 2 og 3) er det den indirekte erververen som er tilbyderen.

\subsubsection{Tilbyderen ved konsolidering}

Loven har regler om at også aksjene til såkalte nærstående skal regnes med ved beregningen av

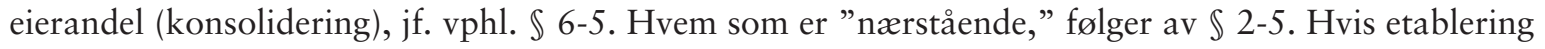
av et nærståendeforhold etter $\mathbb{2}$ 2-5 ikke fører til at de nærstående (gruppen) samlet eier mer enn en 1/3, 40 eller 50 prosent, følger det av forarbeidene at tilbudsplikten påhviler den parten som foretar det erverv som gjør at gruppen krysser en tilbudspliktgrense. Dette gjelder selv om denne partens eierandel er ubetydelig. Et alternativ som ble vurdert var å legge tilbudsplikten på den i gruppen med størst eierandel, men dette ble avvist av rettstekniske hensyn og av hensyn til forutberegnelighet for aksjeeieren. Dessuten, hvis aksjeeieren med størst eierandel blir pålagt tilbudsplikt, må det rimeligvis også være han som innehar nedsalgsretten. Men ifølge forarbeidene er det lite naturlig at han, om han ikke ønsker å fremme tilbud, må selge sine aksjer når det er en annen som har utløst tilbudsplikten. ${ }^{18}$

Etablering av et nærståendeforhold som gjør at gruppen blir eier av mer enn 1/3, 40 eller 50 prosent, innebærer ikke noe "erverv" som kan utløse tilbudsplikt etter vphl. $\mathbb{S} 6-1(1)$. Men "aksjeeier som har passert tilbudspliktgrense [...] på en måte som ikke utløser tilbudsplikt, og derfor ikke har fremsatt pliktig tilbud, plikter ved ethvert etterfølgende erverv som øker stemmeandelen, å gi tilbud,” jf. $\mathbb{S}$ 6-6(2). Denne bestemmelsen gjelder også ved konsolidering, jf. $\mathbb{S}$ 6-5. Dermed er det den parten som foretar det første ervervet etter konsolideringen, som er å anse som tilbyderen. ${ }^{19}$

I ett tilfelle kan likevel etablering av et nærståendeforhold som gjør at gruppen blir eier av mer enn 1/3, 40 eller 50 prosent, utløse tilbudsplikt. Det gjelder for etablering av et konsern etter vphl. $\mathbb{S} 2-5$ nr. 3, hvis dette samtidig er et indirekte erverv etter $\mathbb{6}$ 6-1(2) nr. 1 og 3. F.eks. ble Inship og Paal Wilson konsolidert som konsern (se punkt 4.1.2).

\footnotetext{
16 Et slikt samarbeid gir etter mitt syn ikke grunnlag for konsolidering, jf. vphl. § 2-5 nr. 5.

17 Oslo Børs (2001) s. 84.

$18 \quad$ NOU 1996:2 s. 118.

$19 \quad$ NOU 1996:2 s. 14 og 117
} 


\subsection{Tilbyderens nærstående}

Ved konsolidering er altså tilbyderen enten den som foretar det ervervet som gjør at gruppen krysser en tilbudspliktgrense, den som foretar det første ervervet etter konsolideringen eller en indirekte erverver. Et spørsmål er om vederlag avtalt eller betalt av en annen i den konsoliderte gruppen (tilbyderens nærstående) kan få betydning for tilbudsprisen.

\subsubsection{Hovedregelen}

Ifølge vphl. \$ 6-10 fjerde og femte ledd er det bare vederlag fra "tilbyderen” som kan få betydning. Spørsmålet må derfor bero på en fortolkning av $\mathbb{S}$ 6-5(1) første pktm. som bestemmer: "I forhold til reglene om tilbudsplikt regnes like med en aksjeeiers egne aksjer, aksjer som eies eller erverves av nærstående som nevnt i $\mathbb{S} 2-5$." Uttrykket "reglene om tilbudsplikt" er etter mitt syn entydig og omfatter isolert sett alle reglene om tilbudsplikt i kap. 6, jf. også kapitteloverskriften. Men neste del av setningen om at en aksjeeiers egne "aksjer" regnes like med nærståndes "aksjer," er det bare naturlig å forstå slik at aksjene skal legges sammen ved beregningen av om tilbudsplikt er utløst, og ikke som at vederlag fra tilbyderens nærstående kan få betydning for tilbudsprisen. Det står ikke at nærståendes vederlag skal regnes like med en aksjeeiers eget vederlag. Spørsmålet om vederlag fra tilbyderens nærstående kan få betydning for tilbudsprisen, må dermed bero på en utvidende, nærmest analogisk, fortolkning av $\$ 6$ 6-5(1) første pktm.

Hensikten med lovrevisjonen var å gjennomføre tre EØS-relevante direktiver for verdipapirmarkedet, herunder direktivet om overtakelsestilbud. ${ }^{20}$ Ifølge dette direktivet skal man regne med vederlag fra nærstående ("persons acting in concert with him"), jf. art 5(4) første pktm. Forarbeidene slår fast at "etter vphl. $\mathbb{S} 4-5$ vil den prisen nærstående betaler eller avtaler måtte medregnes." ${ }^{21}$ Det ble ikke ansett nødvendig å foreslå materielle endringer i reglene om tilbudspris. ${ }^{22}$ Forarbeidene gir således klart uttrykk for at vederlag fra tilbyderens nærstående kan få betydning for tilbudsprisen. Dette må, til tross for forarbeidenes ordlyd, gjelde selv om vederlaget er betalt før etablering av nærståendeforholdet. I samme retning trekker uttalelser fra Børsklagenemnden og Børsen i anledning Eastern Drilling-saken, ${ }^{23}$ City Code regel 9.5 og juridisk litteratur. ${ }^{24}$

Også formålet om likebehandling trekker i retning av at vederlag fra tilbyderens nærstående kan få betydning for tilbudsprisen, fordi slike vederlag kan inneholde en kontrollpremie. Hvis vederlag fra tilbyderens nærstående ikke skulle ha betydning, vil det med andre ord være nokså enkelt å unndra (den høyeste) kontrollpremien som er betalt i vederlagsperioden. Et eksempel: Hvis en oppkjøper har kjøpt aksjer i målselskapet, og kursen kort tid etter har falt, kan han være interessert i å kjøpe flere aksjer nokså umiddelbart. Men for at ikke vederlaget etter hans aksjekjøp skal bli lagt til grunn for tilbudsprisen, må han vente i seks måneder før han kjøper nye. Hvis vederlag fra tilbyderens nærstående ikke kan få betydning for tilbudsprisen, kan oppkjøperen i stedet få en nærstående, som da vil bli tilbyderen, til å kjøpe den aksjeposten som gjør at gruppen krysser tilbudspliktgrensen.

I motsatt retning trekker enkelte reelle hensyn. En regel om konsolidering med hensyn på vederlag kan virke svært tyngende. Riktignok kan det være en marginal differanse mellom vederlaget fra tilbyderens nærstående og vederlaget fra tilbyderen. Men det er også mulig at vederlaget fra tilbyderens nærstående er betydelig større enn vederlaget fra tilbyderen, og alene denne muligheten må tale mot en regel om konsolidering med hensyn på vederlag. Et ekstremt eksempel gir Eastern Drilling-saken. Her har tilbyderens nærstående, Carnegie, betalt et vederlag for aksjer i Eastern Drilling som er nesten 50

\footnotetext{
$20 \quad$ NOU 2005:17 s. 11.

21 Vphl. 1997 § $4-5$ tilsvarer vphl. § 6-5.

22 NOU 2005:17 s. 41-42.

23 Oslo Børs (2006) s. 108, Oslo Børs brev 8.1.07 s. 4.

24 Bechmann (2002) s. 290 og 330.
} 
prosent høyere enn det Seadrill har betalt. Ettersom Børsen la til grunn at tilbudsprisen måtte basere seg på vederlaget fra Carnegie, ble Seadrill påført en ekstrakostnad etter gjennomført pliktig tilbud på ca kr 850 mill. ${ }^{25}$ Til dette kommer et annet hensyn: En konsolidering med hensyn på vederlag er mer rimelig ved de tette samarbeid, der partene gjerne har nokså god kjennskap til hverandres erverv og vederlag, enn ved mer løse forbindelser. Men skal det først skje en konsolidering med hensyn på vederlag, må det gjelde alle grader av samarbeid slik loven er formulert.

Når bl.a. klare forarbeider og formål står mot reelle hensyn, må konklusjonen være at vederlag fra tilbyderens nærstående, i hvert fall som hovedregel, kan få betydning for tilbudsprisen. Det er kritikkverdig at forarbeidene ikke foretar noen nærmere begrunnelse for en så vidtrekkende regel, og at den ikke fremgår av lovens ordlyd. I de neste punktene 4.2.2 til 4.2.4 blir det vurdert om enkelte forhold kan tilsi unntak fra regelen.

\subsubsection{Vederlag fra nærstående avtalt eller betalt etter utløsning av tilbudsplikt}

Et spørsmål er om det må gjøres unntak for vederlag fra tilbyderens nærstående avtalt eller betalt etter utløsning av tilbudsplikt, men før utløpet av vederlagsperioden (se punkt 5.1).

Etter mitt syn skiller ikke rettskildesituasjonen seg særlig fra den som er nevnt i punkt 4.2.1. Det kan muligens hevdes at det er mindre rimelig å la slike etterfølgende vederlag få betydning for tilbudsprisen enn vederlag avtalt eller betalt i seksmånedersperioden. Men dette gjelder i så fall også utenfor konsolideringstilfellene, og da er regelen klart nok at etterfølgende vederlag kan få betydning for tilbudsprisen (se punkt 5.3.1). Tanken er at slike vederlag kan inneholde en kontrollpremie som det er naturlig at minoritetsaksjeeierne får en del av. Konklusjonen er at det ikke er grunnlag for unntak for vederlag fra tilbyderens nærstående avtalt eller betalt etter utløsning av tilbudsplikt.

\subsubsection{Vederlag fra nærstående for aksjer som ikke er omfattet av samarbeid}

Som tilbyderens nærstående menes f.eks. "noen som det må antas at vedkommende har forpliktende samarbeid med når det gjelder å gjøre bruk av rettighetene som eier av et finansielt instrument," jf. vphl. $\$ 2-5 \mathrm{nr}$. 5. Et slikt samarbeid trenger ikke omfatte alle partenes eksisterende eller fremtidige finansielle instrumenter i et bestemt selskap, men kan gjelde en begrenset del av dem (samarbeidsaksjer), som f.eks. bare aksjer ervervet som hedge under en TRS-avtale (se punkt 14.1.1). Hvis en part utløser tilbudsplikt, er spørsmålet om vederlag fra den andre parten (tilbyderens nærstående) for aksjer som ikke er omfattet av samarbeidet, kan få betydning for tilbudsprisen. Tilbyderens nærstående kan ha kjøpt andre aksjer f.eks. i egenskap av megler eller som hedge under en (annen) TRS-avtale.

Forarbeidene gir etter mitt syn ingen veiledning, fordi det ikke blir sagt noe om hva vederlaget fra tilbyderens nærstående må være betalt for. Formålet om likebehandling trekker i retning av at vederlag for andre aksjer ikke kan få betydning for tilbudsprisen, fordi slike vederlag ikke kan inneholde en (relevant) kontrollpremie. I motsatt retning trekker i hvert fall et rettsteknisk hensyn. Det kan være vanskelig, om ikke umulig, å skille vederlag for samarbeidsaksjer og andre aksjer, særlig der tilbyderens nærstående er et verdipapirforetak som normalt foretar stadige handler i aksjene, og der derivatkontrakter blir rullert. Dette hensynet er imidlertid ikke særlig tungtveiende. For hvis regelen er at vederlag for andre aksjer enn samarbeidsaksjer ikke kan få betydning for tilbudsprisen, må tvil om hvilke vederlag som er betalt for hvilke aksjer, gå ut over den konsoliderte gruppen. ${ }^{26}$ Dette vil formodentlig føre til at gruppen sikrer den nødvendige dokumentasjon.

Konklusjonen må være at vederlag fra tilbyderens nærstående for andre aksjer enn samarbeidsaksjer $i k k e$ kan få betydning for tilbudsprisen.

25 Oslo Børs (2006) s. 90 flg.

26 Jf. alminnelige prinsipper om tvilsrisiko. 


\subsubsection{Vederlag avtalt eller betalt av en tidligere nærstående}

Hvis et nærståendeforhold opphører, og tilbudsplikt deretter blir utløst, er spørsmålet om vederlag avtalt eller betalt av tilbyderens tidligere nærstående kan få betydning for tilbudsprisen.

Vphl. $\mathbb{S}$ 6-5(1) første pktm. gjelder "nærstående som nevnt i $\mathbb{S} 2-5$," d.v.s. en som tilbyderen f.eks. "bor" sammen med, "har" innflytelse over eller "har" et samarbeid med. Utenfor faller således en som tilbyderen f.eks. bodde sammen med, hadde innflytelse over, eller hadde et samarbeid med. Spørsmålet om vederlag fra tilbyderens tidligere nærstående kan få betydning for tilbudsprisen, må i tilfelle bero på en utpreget analogisk fortolkning av $\mathbb{\$} 6$-5(1). Ifølge direktivet skal man regne med vederlag fra personer "acting" etter overenskommelse med tilbyderen, jf. art 5(4) første pktm. Forarbeidene gjelder den prisen "nærstående" betaler eller avtaler og trekker dermed i retning av at vederlag fra tilbyderens tidligere nærstående ikke kan få betydning for tilbudsprisen. I samme retning trekker også Børsens holdning til spørsmålet om en utløst tilbudsplikt bortfaller etter opphør av et nærståendeforhold. ${ }^{27}$

Konklusjonen må klart nok være at vederlag avtalt eller betalt av tilbyderens tidligere nærstående $i k k e$ kan få betydning for tilbudsprisen. Ettersom regelen er klar, vil en tilknyttet tvist dreie seg om et nærståendeforhold faktisk er opphørt eller ikke ved utløsning av tilbudsplikt. Eastern Drilling-saken kan brukes som illustrasjon. 6. april 2006 ble Seadrill og Carnegie konsolidert. 7. september utløste Seadrill tilbudsplikt. Fra Seadrills side ble det for tingretten anført at et eventuelt samarbeid med Carnegie var opphørt allerede i løpet av våren/sommeren. For fra da av var ikke lenger Seadrills dominans i Eastern Drilling utfordret av Ocean Rig, slik at et videre samarbeid om bruk av eierrettighetene knyttet til sikringsaksjene ville ha vært grunnløst (se punkt 14.1.1). 


\subsection{Vederlagsperioden}

Et vederlag som er avtalt eller betalt "i perioden 6 måneder før tilbudsplikten inntrådte," kan få betydning for tilbudsprisen, jf. vphl. $\mathbb{6} 6-10(4)$ første pktm. Tilbudsplikten inntrer når tilbyderen "gjennom erverv blir eier" av de aksjene som utløser tilbudsplikten (se punkt 5.2.2), jf. $\mathbb{\$}$ 6-1 og 6-6. Dersom tilbyderen etter at tilbudsplikten inntrådte og før utløpet av tilbudsperioden har avtalt eller betalt høyere vederlag enn tilbudsprisen, skal nytt tilbud anses fremsatt med en tilbudspris som svarer til det høyere vederlag, jf. $\$$ 6-10(5) første pktm. Tilbudsperioden forlenges da automatisk slik at det gjenstår minst to uker til dens utløp, jf. $\mathbb{S}$ 6-10(5) annet pktm. og 6-12(2). Dette innebærer at den relevante perioden strekker seg fra seks måneder før tilbudsplikten inntrådte og frem til utløpet av den alminnelige eller forlengede tilbudsperioden (vederlagsperioden). I tid kan vederlagsperioden tilsvare åtte og en halv måned, eventuelt ni måneder hvis tilbudsperioden er maksimalt forlenget, jf. $\mathbb{S}$ 6-10(1) og 6-11(1).

\subsection{Vederlag betalt før vederlagsperioden}

Et vederlag som er betalt før vederlagsperioden kan ikke få betydning for tilbudsprisen.

\subsubsection{Vederlag ved erverv av eierandel nær tilbudspliktgrensen}

Dette betyr at en oppkjøper kan erverve og betale for aksjer som bringer han nær $1 / 3$, og deretter vente i seks måneder før han til en eventuell lavere aksjekurs erverver den siste lille aksjeposten som bringer han over 1/3. I så fall er det den lavere aksjekursen som skal legges til grunn for tilbudsprisen. Ifølge forarbeidene er begrunnelsen at oppkjøperen har "påtatt seg en risiko ved å sitte og vente på eventuelle endringer i aksjekursen." ${ }^{28}$ Det var på denne måten Kjell Inge Røkke sikret seg kontrollen i Aker RGI og Alcoa Inc i Elkem. ${ }^{29}$

\subsubsection{Vederlag der tilbyderen blir eier i vederlagsperioden}

Et vilkår for utløsning av tilbudsplikt er at oppkjøperen "blir eier" av aksjer, som ifølge forarbeidene er ved avtaleslutning. Tidspunktet for oppgjør vil ikke ha noen selvstendig betydning. ${ }^{30}$ Formålet med tilbudspliktreglene og Børsens praksis trekker derimot i retning av at det er tidspunktet for oppgjør, d.v.s. overføring av eierbeføyelsene herunder stemmeretten, som er avgjørende. ${ }^{31}$ Men hvis dette siste er riktig, blir det en noe merkelig sammenheng i loven. For da kan ikke et vederlag som er betalt før vederlagsperioden få betydning for tilbudsprisen, selv om vederlaget er knyttet til det ervervet som gjør at en oppkjøper krysser tilbudspliktgrensen. En annen sak er at forhåndsbetaling av aksjer er upraktisk.

\subsection{Vederlag avtalt eller betalt i vederlagsperioden}

Et vederlag som er avtalt eller betalt i vederlagsperioden kan få betydning for tilbudsprisen. Dette betyr at et vederlag som er avtalt før perioden kan få betydning hvis det er betalt i perioden, og at et vederlag som er avtalt i perioden kan få betydning selv om det blir betalt etter utløpet av perioden. ${ }^{32}$

\subsubsection{Vederlag avtalt eller betalt etter utløsning av tilbudsplikt}

Dersom det blir avtalt eller betalt et høyere vederlag etter at tilbudsplikten inntrådte, men før utløpet av tilbudsperioden, er rettsvirkningen mer presist at "nytt tilbud skal anses fremsatt med en tilbudspris som svarer til det høyere vederlag," jf. vphl. $\$$ 6-10(5). I dette ligger ikke at tilbyderen må utarbeide

$\begin{array}{ll}28 & \text { NOU 1996:2 s. } 122 . \\ 29 & \text { Oslo Børs (2005) s. } 68 \text { flg. } \\ 30 & \text { NOU 1996:2 s. } 100 \text { og 120. } \\ 31 & \text { Oslo Børs (2001) s. 91-93. } \\ 32 & \text { Et vederlag som er avtalt før og betalt etter vederlagsperioden er naturligvis uten betydning. }\end{array}$


et nytt tilbudsdokument, men at tilbudsprisen automatisk blir oppjustert. Det må imidlertid kreves at tilbyderen offentliggjør den oppjusterte tilbudsprisen. Loven sier ikke noe om hvordan dette skal skje. I juridisk litteratur er det tatt til orde for at tilbyderen "må sende et varsel til samtlige aksjeeiere og samtidig bekjentgjøre tilbudsprisen gjennom børsens meldingssystem." 33

Lovens ordlyd er ikke treffende når det gjelder vederlag som er avtalt eller betalt etter at tilbudsplikten inntrådte, men før tilbud ble fremsatt. Hvis et slikt vederlag er det høyeste, foreligger det ikke noe tilbud som et tilbud basert på dette vederlaget kan være "nytt" i forhold til. I så fall må tilbyderen utarbeide et tilbudsdokument med en tilbudspris som tilsvarer det høyeste vederlaget.

\subsubsection{Vederlag der tilbyderen ikke blir eier i vederlagsperioden}

Et vederlag som er avtalt eller betalt for aksjer i vederlagsperioden kan få betydning for tilbudsprisen, selv om tilbyderen ikke blir eier av aksjene i perioden. ${ }^{34}$ Hvis det ved fremsettelse av pliktig tilbud er usikkert om tilbyderen noen gang blir eier, f.eks. fordi aksjeavtalen er avhengig av en betingelse som ikke er inntrådt, må dette tas i betraktning ved verdsettelsen av vederlaget (se punkt 8.3.1).

\subsubsection{Vederlag i overlappende vederlagsperioder (gjentatt tilbudsplikt)}

En tilbyder som etter gjennomført pliktig tilbud er blitt eier av mellom 1/3 og 40 prosent, kan nokså kort tid etter utløpet av vederlagsperioden tenkes å erverve aksjer som bringer han over 40 prosent. I en slik situasjon kan ett og samme vederlag være avtalt eller betalt både i vederlagsperioden for første- og annengangs tilbudsplikt. Hvis dette vederlaget er høyere enn noe annet vederlag tilbyderen har betalt for aksjene som utløste annengangs tilbudsplikt, er spørsmålet om det kan bli lagt til grunn for annengangs tilbudspris. Samme spørsmål kan naturligvis oppstå der ett og samme vederlag er avtalt eller betalt i vederlagsperioden både for annen- og tredjegangs tilbudsplikt.

Svaret må klart nok være at vederlaget kan bli lagt til grunn for annengangs/tredjegangs tilbudspris, jf. ordlyden i $\$ 6-10(4)$ første pktm. Hvis vederlaget ble lagt til grunn for tilbudsprisen ved førstegangs/ annengangs tilbudsplikt, kan det hevdes at minoritetsaksjeeierne ikke har noen beskyttelsesverdig forventning om å bli tilbudt den en gang til. Men alene kan ikke dette innskrenke ordlyden.

\subsubsection{Alternativt oppgjør i pliktig tilbud som vederlag}

Oppgjør i henhold til tilbudet skal skje i penger, men et tilbud kan også gi aksjeeierne rett til å velge annet oppgjør (alternativt oppgjør), jf. vphl. $\$$ 6-10(6). Et alternativt oppgjør kan anses som et spesielt vederlag avtalt i tilbudsperioden. Dersom dette er høyere enn tilbudsprisen i pengeoppgiøret, må pengeoppgjøret oppjusteres tilsvarende, eller det alternative oppgjøret nedjusteres (før noen har akseptert det), jf. $\$ 6-10(5) .{ }^{35}$ I juridisk litteratur er det stilt spørsmål ved om dette kan være gjeldende rett, fordi "lovens siktemål er å sikre aksjeeierne et kontanttilbud til en viss minstepris, og at det ikke er noen grunn til å forby at de også tilbys et mer verdifullt alternativ med oppgjør i aksjer og lignende.” ${ }^{36}$ Litteraturen overser imidlertid lovens klare ordlyd.

\subsection{Vederlag avtalt etter vederlagsperioden}

Et vederlag som er avtalt etter vederlagsperioden kan ikke få betydning for tilbudsprisen (med unntak for gjentatt tilbudsplikt). Dette betyr at en tilbyder straks etter perioden kan erverve aksjer til høyere vederlag enn tilbudsprisen. Et eksempel gir Akers oppkjøp av Natural ASA i 2006. Oppkjøpet ble gjort i tre ledd: Først ble det fremsatt et frivillig tilbud, deretter et pliktig tilbud og straks etter vederlagsperioden ble det kjøpt større poster av selskapets grunnlegger og storaksjeeier, Jan Remmereit. Tilbudsprisen

\footnotetext{
33 Bechmann (2002) s. 340.

34 Forutsetningen er at tilbyderen ikke "blir eier" fra avtaletidspunktet (se punkt 5.2.2).

$35 \quad$ NOU 1996:2 s. 123.

36 Bechmann (2002) s. 329.
} 
i det pliktige tilbudet var kr 57. Men det ble reist spørsmål ved om Remmereit fikk mer. ${ }^{37}$ Oppgjøret etter det pliktige tilbudet var i penger. Remmereit fikk bl.a. oppgjør i form av aksjer i Aker Biomarine kombinert med en opsjon til å selge disse tilbake til Aker for det som ville bli kursen i en planlagt emisjon. En salgsopsjon har en verdi (se punkt 8.2.5), som hedgefondet Warren Wicklund beregnet til ca kr 17 pr. aksje i Natural.

Man kan bl.a. anføre at slike etterfølgende erverv strider mot formålet om likebehandling, særlig hvis tilbudsprisen ikke inneholdt noen kontrollpremie av betydning. Lovutvalgets flertall foreslo derfor en bestemmelse om at en "tilbyder som kjøper eller avtaler kjøp til høyere pris enn tilbudsprisen innen seks måneder etter utløpet av tilbudsperioden, skal betale differansen mellom høyeste betalte eller avtalte pris og tilbudsprisen til aksjeeiere som har akseptert tilbudet" (etterkompensasjon). ${ }^{38}$ I Sverige har regler om etterkompensasjon eksistert i mange år (jf. takeover-reglene punkt II.12), mens man i Storbritannia lenge har hatt et forbud mot etterfølgende erverv (jf. City Code regel 35). Verken Danmark eller Finland har slike regler. Når det ikke ble noe av utvalgets forslag om etterkompensasjon, skyldes dette i første rekke at "forslaget innebærer at kjøper vil måtte kompensere tidligere kjøpere av aksjer for eventuell kursstigning i de påfølgende seks måneder, dersom kjøper erverver ytterligere aksjer til høyere pris." ${ }^{39}$ Tanken må være at dette er urimelig hvis kursstigningen ikke skyldes betaling av en kontrollpremie. Her kan det legges til at minoritetsaksjeeierne allerede etter dagens regler undertiden mottar en viss kompensasjon for høyere etterfølgende erverv, fordi en del av tilbudsprisen representerer verdien av en rett til etterkompensasjon som tidligere selgere er tilbudt (se punkt 8.3.2).

37 Se f.eks. Jensen (2006).

$38 \quad$ NOU 2005:17 s. 39.

39 Ot. prp. nr. 34 (2006-1007) s. 381. 
For at et vederlag skal kunne få betydning for tilbudsprisen, må det være "betalt eller avtalt" i vederlagsperioden, jf. vphl. $\$$ 6-10 fjerde og femte ledd. Avtale- og betalingstidspunktet kan dessuten ha betydning ved verdsettelsen (se punkt 9).

\subsection{Avtalealternativet}

Normalt byr det ikke på problemer å ta stilling til når et vederlag er avtalt. Her blir enkelte typiske tvilstilfeller behandlet.

\subsubsection{Opsjoner. Vederlag avtalt ved inngåelse eller innløsning?}

En opsjon kan gi utstederen plikt til å selge/kjøpe fysiske aksjer, mens innehaveren en rett til å kjøpe selge aksjer til en på forhånd fastsatt pris (innløsningspris) innen eller til en bestemt tid. For denne retten yter innehaveren betaling (opsjonspremie) til utstederen. Ettersom det bare er vederlag for eiendomsrett til aksjer som kan få betydning for tilbudsprisen (se punkt 11), er opsjonspremien uten interesse i denne sammenheng. Spørsmålet er om innløsningsprisen er avtalt ved inngåelsen av opsjonsavtalen eller ved innløsning av opsjonen. ${ }^{40}$ Dette har praktisk betydning hvis inngåelsen av opsjonsavtalen skjer i vederlagsperioden, og opsjonen $i k k e$ blir innløst i perioden. ${ }^{41}$

Det er naturlig å si at innløsningsprisen er avtalt ved inngåelsen av opsjonsavtalen, fordi partene da er enige om denne prisen som skal ligge til grunn for opsjonen og en eventuell fremtidig avtale om $\mathrm{kjøp} / \mathrm{salg}$ av aksjer. På den annen side, etter en stringent juridisk forståelse er innløsningsprisen først "avtalt" når den er del av en rettslig bindende avtale, d.v.s. at både utstederen og innehaveren må være rettslig forpliktet. Et minstekrav for rettslig forpliktethet er at den berettigede i prinsippet kan få fastsettelsesdom for oppfyllelse av forpliktelsen (enten in natura eller i form av erstatning). ${ }^{42}$ En opsjon skaper en slik form for forpliktelse for utstederen fra inngåelse av opsjonsavtalen, men innehaveren blir først forpliktet ved innløsning. Etter mitt syn må dette helst bety at ordlyden ikke gir noen veiledning i denne sammenheng.

Dersom en innløsningspris er å anse som avtalt ved inngåelsen av opsjonsavtalen, må den kunne få betydning for tilbudsprisen selv om den er knyttet til en opsjon som ikke er innløst i vederlagsperioden. Dette fremstår ikke umiddelbart som rimelig. Hvis det etter vederlagsperioden viser seg at innehaveren avstår fra å innløse opsjonen, kan tilbudsprisen være basert på et vederlag som aldri vil bli betalt. Noen stor risiko for at tilbudsprisen blir basert på innløsningsprisen etter en kjøpsopsjon som ikke er innløst i vederlagsperioden, er det imidlertid ikke. De underliggende aksjene kan ikke tas med ved beregningen av om tilbudsplikt er utløst, jf. vphl. $\mathbb{S} 6-1(1)$. Ved siden av kjøpsopsjonene må derfor tilbyderen, for at tilbudsplikt skal være utløst, også ha ervervet eiendomsrett til aksjer. Innløsningsprisen kan bare bli lagt til grunn for tilbudsprisen hvis prisen er høyere enn noe annet vederlag tilbyderen har betalt for aksjer. Dette forutsetter at aksjekursen har falt etter inngåelse av opsjonsavtalen. Men i så fall er det usikkert om tilbyderen noen gang kommer til å innløse kjøpsopsjonene. En slik usikkerhet må tas i betraktning ved verdsettelsen av innløsningsprisen slik at den ikke kan få betydning med sin fulle kroneverdi (se punkt 8.3.1). Dermed antar jeg at innløsningsprisen ofte blir verdsatt lavere enn et vederlag for de øvrige aksjene. Annerledes for innløsningsprisen etter en salgsopsjon. For når innløsningsprisen er høyere enn aksjekursen, er det nokså sikkert at

$40 \quad$ Forutsetningen her er at det dreier seg om en opsjon, og ikke om et reelt erverv av aksjer. I sistnevnte tilfelle er også opsjonspremien vederlag for aksjer, og innløsningsprisen er avtalt ved inngåelse av "opsjonsavtalen." Dessuten må det dreie seg om opsjoner med fysisk oppgjør. Ved opsjoner med finansielt oppgjør er heller ikke innløsningsprisen betaling for eiendomsrett til aksjer (se punkt 11.1.1).

41 Dessuten kan spørsmålet ha betydning hvis tilbudsplikt blir utløst ved erverv av opsjoner (se punkt 14.2.3).

42 I avtalerettslig litteratur er nettopp dom for oppfyllelse trukket frem som kjennetegnet ved en gyldig (rettslig bindende) avtale, jf. f.eks. Hov (2002) s. 26. Om fastsettelsesdom, se tvistemålsloven § 54. 
innehaveren vil innløse opsjonen. Men dermed er det uten betenkeligheter å legge innløsningsprisen til grunn for tilbudsprisen, selv om opsjonen ikke er innløst ved fremsettelse av tilbud eller i vederlagsperioden. Etter dette kan ikke rimelighetshensyn stå i veien for at innløsningsprisen er avtalt ved inngåelsen av opsjonsavtalen, men hensynet er heller ikke et argument i noen retning.

I mangel av andre rettskilder må løsningen anses usikker.

\subsubsection{Betingede avtaler. Vederlag avtalt ved aksept eller inntreden av betingelser?}

Det er vanlig å snakke om betingede avtaler, f.eks. av at det blir foretatt en due diligence i målselskapet. Betingede avtaler kommer i stand ved at et betinget tilbud blir akseptert før betingelsen er oppfylt. Spørsmålet er om vederlaget etter en betinget avtale er å anse som avtalt fra aksepttidspunktet eller først når betingelsen inntrer. ${ }^{43}$ Dette kommer særlig på spissen hvis aksept finner sted i vederlagsperioden, og betingelsen ikke inntrer i perioden. Men spørsmålet kan ha praktisk betydning, selv om betingelsen inntrer i perioden siden verdsettelsen av vederlaget normalt skal være knyttet til avtaletidspunktet (se punkt 9).

Etter en opsjon er det bare utstederen som er rettslig forpliktet, slik at det ikke er helt naturlig å si at innløsningsprisen er avtalt før innløsning (se forrige punkt). Etter en betinget avtale er imidlertid begge parter rettslig forpliktet før betingelsen er oppfylt. ${ }^{44}$ Partene kan i prinsippet få fastsettelsesdom for oppfyllelse, ${ }^{45}$ men ikke fullbyrdelsesdom før betingelsen er inntrådt. ${ }^{46}$ Dermed er ordlyden her et argument for at vederlaget er avtalt fra aksepttidspunktet.

I Navis-saken uttalte Børsen at "språklig sett omfattes også en avtale som dette hvor en av betingelsene fortsatt utestår.” Og som en konsekvens måtte Fred Olsens Energys betingede avtale med Reading \& Bates Falcon i prinsippet bli hensyntatt ved fastsettelse av tilbudsprisen. ${ }^{47}$ I motsatt retning trekker riktignok et liknende konsekvenshensyn som nevnt i forrige punkt, men dette kan ikke alene være avgjørende. Hvis det ved fremsettelse av pliktig tilbud er usikkert om betingelsen noen gang vil bli oppfylt, må usikkerheten tas i betraktning ved verdsettelsen av vederlaget (se punkt 8.3.1).

Konklusjonen er at vederlag etter en betinget avtale, i hvert fall som hovedregel, er å anse som avtalt fra aksepttidspunktet.

\subsubsection{Frivillige tilbud. Vederlag avtalt ved den enkelte aksept eller inntreden av betingelser?}

Anvendt på den normale oppkjøpssituasjonen der det er fremsatt frivillig tilbud, skulle konklusjonen i forrige punkt tilsi at vederlaget blir avtalt ved den enkelte aksept, og ikke ved inntreden av betingelsene f.eks. om en bestemt akseptgrad. Det kan imidlertid reises spørsmål ved om det i denne sammenheng må gjøres unntak fra regelen om at vederlaget etter en betinget avtale er å anse som avtalt ved aksept.

Etter en juridisk forståelse blir vederlaget avtalt ved den enkelte aksept. For fra dette tidspunktet kan partene kreve fastsettelsesdom for oppfyllelse. ${ }^{48}$ Som ved betingede avtaler ellers må ordlyden være et argument for at vederlaget er avtalt fra aksepttidspunktet. I motsatt retning trekker praksis fra Børsklagenemnden. Bl.a. i Hitec-saken slår Nemnden fast at det er "det tidspunktet da tilbyderen ble

43 Det dreier seg her om suspensivt betingede avtaler. Vederlaget etter en resolutivt betinget avtale er klart nok å anse som "avtalt" ved aksepttidspunktet. Om betingelser, se Hov (2002) s. 86 flg.

44 Dette gjelder i sin alminnelighet. Men enhver avtale må naturligvis vurderes konkret.

45 Partene kan tenkes å ha rettslig interesse i fastsettelsesdom før en avtalebetingelse er oppfylt.

$46 \quad$ Tvistemålsloven $§ 53$.

$47 \quad$ Oslo Børs (2000) s. 81.

48 Forutsetningen må være at tilbyderen ikke (lovlig) har forbeholdt seg en rett til fritt å kunne trekke tilbake "tilbudet" selv etter at det er akseptert. 
ubetinget bundet av det frivillige tilbudet, som vil være avgjørende for verdifastsettelsen.” ${ }^{49}$ Dette må bety at Nemnden anser vederlaget som avtalt når tilbudet ble ubetinget. At det er avtaletidspunktet som skal være avgjørende (ved verdsettelsen), følger også av Børsens praksis. ${ }^{50}$

Rimelighetshensyn tilsier et skille mellom såkalte potestative og kasuelle betingelser. En betingelse er potestativ der det står i løftegiverens eller løftemottakerens makt om den skal inntre, mens inntreden av en kasuell betingelse er avhengig av en tilfeldig begivenhet. ${ }^{51}$ Etter mitt syn må det uten videre være klart at vederlaget kan være avtalt, selv om en potestativ betingelse ikke er inntrådt. En annen løsning lar i realiteten verdsettelsestidspunktet være i tilbyderens makt, og han vil da kunne passe på at betingelsen inntrer når vederlaget er verdt minst. Rimelighetshensyn står imidlertid ikke i veien for en regel om at vederlaget ikke er avtalt før inntreden av en kasuell betingelse. Men rettstekniske hensyn er et argument mot et skille mellom potestative og kasuelle betingelser. For grensen mellom slike betingelser er ikke skarp, siden løftegiver eller løftemottaker kan ha større eller mindre makt over inntreden av en betingelse. Når rimelighetshensyn står mot rettstekniske hensyn må det være mest riktig å si at reelle hensyn ikke gir noen veiledning i denne sammenheng.

Konklusjonen er etter mitt syn at vederlaget etter et frivillig tilbud er avtalt ved den enkelte aksept. Dette vil i første rekke ha praktisk betydning ved verdsettelsen av vederlag (se punkt 9.2).

\subsubsection{Vederlag etter ugyldige avtaler (nulliteter)}

Med ordet "avtalt" må man forstå gyldig avtalt. Hvis avtalen har vært ugyldig fra starten av (nullitet), kan ikke vederlaget etter avtalen få betydning for tilbudsprisen. Et eksempel kan være at selgeren har fortiet vesentlige mangler ved målselskapet, jf. avtaleloven $\mathbb{3} 3$. Slike mangler vil normalt bli avdekket senest i tilbudsperioden.

\subsubsection{Vederlag etter avtaler som er falt bort}

For øvrig er ordet "avtalt" tvetydig. Det kan bety "avtalt og ikke senere falt bort," f.eks. fordi avtalen blir hevet, kjent uvirksom (ugyldig) p.g.a. senere inntrådte forhold eller ved inntreden av en resolutiv betingelse. Men et vederlag kan også være "avtalt" hvis tilbyderen (eller andre) på et eller annet tidspunkt har bundet seg til å betale det. Ingen formelle rettskilder gir noen veiledning ved valget av tolkingsalternativene. Dersom en avtale faller bort i vederlagsperioden før pliktig tilbud er fremsatt, er det ikke rimelig at vederlaget etter avtalen kan få betydning for tilbudsprisen. Det samme gjelder for så vidt også for vederlaget etter en avtale som faller bort etter at tilbud er fremsatt, men det kan anføres at en reduksjon av tilbudsprisen ikke er uten betenkeligheter. Markedet innretter seg etter tilbudet med de følger dette kan få for aksjekursen. ${ }^{52}$ Etter mitt syn kan likevel ikke dette være avgjørende. For usikkerhet knyttet til tilbudets størrelse (eventuelt til om det i det hele tatt blir noe av tilbudet) representerer en risiko som markedsaktørene kan ta i betraktning ved beregning av aksjekursen. Konklusjonen må være at vederlaget etter en avtale som faller bort i vederlagsperioden ikke kan få betydning for tilbudsprisen.

\footnotetext{
49 Oslo Børs (2000) s. 85 flg.

50 Se f.eks. tilbudsdokumenter Transocean og Amersham/Nycomed og Oslo Børs (1999) s. 68.

$51 \quad \operatorname{Hov}(2002)$ s. 86.

52 NOU 1996:2 s. 121, der dette blir fremholdt hva gjelder nedsalgsrett etter at tilbud er fremsatt.
} 


\subsection{Betalingsalternativet}

\subsubsection{Må betalingsalternativet bortfortolkes?}

Vederlaget må være "betalt" eller avtalt i vederlagsperioden. Til tross for ordlyden kan det reises spørsmål ved om betalingsalternativet må bortfortolkes. Dette fordi det er vanskelig å finne noen reell begrunnelse for at et vederlag som er avtalt før og betalt i vederlagsperioden, skal ha betydning for tilbudsprisen. Utover dette tilfellet har ikke betalingsalternativet noen betydning, d.v.s. verken der betaling skjer før eller etter perioden, eller hvis avtale er inngått i perioden. Heller ikke har betalingsalternativet betydning som verdsettelsestidspunkt hvis avtale er inngått i perioden (se punkt 9.1).

Lovens ordlyd og bakgrunn viser at betalingsalternativet må være tilsiktet. Etter lov om verdipapirhandel av 14. juni 1985 nr. 61 (vphl. 1985) $\mathbb{5}$ A femte ledd var bare alternativet "betalt" relevant. Forut

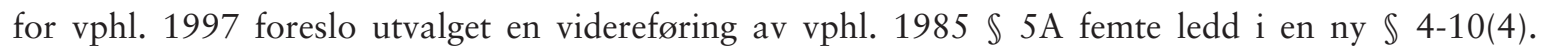
I lovmotivene blir bare alternativet "betalt" omtalt, men i lovutkastet kommer alternativet "avtalt" til syne..$^{53}$ Dersom det var meningen at betalingsalternativet ikke skulle gjelde, ville det ha vært naturlig å fjerne dette samtidig. Vphl. 2007 viderefører vphl. 1997 \$4-10(4) uten videre. ${ }^{54}$

Konklusjonen er at betalingsalternativet ikke kan bortfortolkes.

\subsubsection{Om når vederlag er betalt}

Normalt byr det ikke på tvil å ta stilling til om og når et vederlag er "betalt." Et vederlag i form av aksjer må være "betalt" når eierbeføyelsen går over fra tilbyderen til selgeren (av aksjene i målselskapet), d.v.s. ved registrering på selgerens VPS-konto.

$53 \quad$ NOU 1996:2 s. 210 og 220.

54 Ot. prp. nr. 34 (2006-2007) s. 383. 
Tilbudsprisen skal være minst like høy som det høyeste vederlag, jf. vphl. $\mathbb{\$} 6-10(4)$ første pktm. Hvis et vederlag består av annet enn penger, må det regnes om i penger (verdsettes) fordi oppgjør i henhold til tilbudet skal skje i penger, jf. vphl. 6-10(6) første pktm. Også et vederlag som består av penger, kan reise enkelte verdsettelsesspørsmål, typisk fordi vederlagets valuta er en annen enn den som skal bli lagt til grunn for oppgjøret.

En verdsettelse kan bero på mange skjønnsmessige faktorer. Ifølge Børsen er "det vesentligste" at tilbyderen tilbyr en pris som er "innenfor en forsvarlig ramme" i forhold til vphl. $1997 \$ 4$ 4-10 fjerde ledd. ${ }^{55}$ En slik forståelse av loven må være riktig, men må anvendes med forsiktighet. Tilbudsmyndigheten har ikke noen kompetanse til å godkjenne eller fastsette en tilbudspris som avviker fra det høyeste vederlag.

\subsection{Lovens regler om verdsettelsen er ufravikelige}

Det klare utgangspunktet er naturligvis at partene, d.v.s. tilbyderen og selgeren av kontrollposten, ikke kan avtale noe om verdsettelsen av vederlaget med virkning for tilbudsprisen. ${ }^{56}$ Heller ikke kan tilbyderen i pliktig tilbud bestemme noe om verdsettelsen. I Seadrills frivillige og pliktige tilbud om kjøp av Smedvig ble aksjeeierne tilbudt en rett til tilleggsvederlag for det tilfellet Seadrill kom til å selge aksjer i Smedvig til en høyere pris enn tilbudsprisen innenfor en gitt periode. ${ }^{57}$ I tilbudsdokumentene stod det at "retten er vurdert ikke å ha noen økonomisk verdi." ${ }^{58}$ Tilbudsmyndigheten er naturligvis ikke bundet av tilbyderens oppfatning om verdien av retten. ${ }^{59}$

I praksis har enkelte mer finurlige avtaler om verdsettelsen skapt noe tvil. Et eksempel gir Elkem-saken. ${ }^{60}$ Her hadde selgerne av kontrollposten mottatt kr 235 pluss en betinget rett til tilleggsvederlag. Denne retten skulle falle bort "dersom det i forbindelse med det pliktige tilbudet ble fastslått at kontantverdien av det betingede tilleggsvederlaget var høyere enn” kr 1 pr. aksje. I så fall skulle selgerne i stedet motta et tillegg på kr 1 pr. aksje. Når et vederlag er betinget av at det har en bestemt verdi, kan det hevdes at vederlaget ikke kan verdsettes høyere, simpelthen fordi det ikke eksisterer ved en høyere verdi. Men vederlaget kan klart nok ha en høyere faktisk verdi. F.eks. kan en rett til tilleggsvederlag tenkes å utbringe mer enn verdien den er betinget av. Hvis et vederlag bare blir verdsatt til verdien det er betinget av, vil derfor selgerne av kontrollposten kunne få betalt mer for sine aksjer enn minoritetsaksjeeierne. Dette må være i strid med formålet om likebehandling, slik at det riktige trolig er å se bort fra betingelsen ved verdsettelsen. I Elkem-saken fant ikke Børsklagenemnden det nødvendig å ta stilling til hvordan den skulle forholde seg til betingelsen, men løste verdsettelsen på annet vis (se punkt 8.3.2).

\subsection{Utgangspunktet om samlet økonomisk vederlag}

Etter loven er det "vederlag" som kan få betydning for tilbudsprisen, jf. vphl. $\$$ 6-10(4) første pktm. Ifølge forarbeidene har man ved å bruke begrepet vederlag "søkt å få frem at det er den økonomiske motytelse ved aksjeervervet som skal legges til grunn." ${ }^{61}$ Dette gir lite veiledning, men er formodentlig et forsøk på en presisering av at alle vederlagselementer uavhengig av art skal regnes med. ${ }^{62}$ Ved kjøp

\footnotetext{
$55 \quad$ Nå vphl. § 6-10(4). Oslo Børs (2000) s. 79.

$56 \quad$ Ikke bare reglene om verdsettelse, men alle lovens regler om tilbudspris er naturligvis ufravikelige. Men det er i første rekke spørsmålet om gyldigheten av avtaler om verdsettelsen, som eventuelt kan volde tvil i praksis.

57 En slik rett må være en ulovlig del av et pliktig tilbud, se punkt 8.3.2.

$58 \quad$ Frivillig tilbudsdokument 10.01 .06 (Seadrill/Smedvig), jf. akseptformularet pkt 7. Pliktig tilbudsdokument 2.3.06 s. 5 og 22.

59 En annen sak er at retten til tilleggsvederlag trolig var uten økonomisk verdi, fordi det var lite sannsynlig at Seadrill ville selge aksjer i Smedvig på kort sikt. Om verdsettelsen av en rett til tilleggsvederlag, se punkt 8.3.2.

60 Oslo Børs (2005) s. 68 flg.

61 Ot. prp. nr. 53 (1988-1989) s. 22.

62 Se også NOU 1996:2 s. 109.
} 
i regulert marked er det som regel enkelt å fastslå hva samlet vederlag er, som normalt bare består av en bestemt kjøpesum i norske kroner. Ved kjøp utenfor regulert marked kan vurderingen bli noe vanskeligere, fordi vederlaget her kan bestå av aksjer, eller en kombinasjon av penger og aksjer. Til dette kan det i prinsippet legges alt mulig, f.eks. en fast eiendom eller en tjeneste.

\subsection{Avgrensning mot vederlag av ubetydelig verdi}

Selv om det i prinsippet er tilbyderens samlede vederlag som er avgjørende, må tilbudsmyndigheten i praksis kunne se bort fra vederlagselementer av ubetydelig økonomisk verdi ved godkjenning av tilbudspris. ${ }^{63}$ Noe annet ville ha vært helt uhensiktsmessig, fordi ethvert kontraktsvilkår kan sies å ha en verdi, f.eks. et vilkår som gir selgeren (av aksjene i målselskapet) en utvidet rett til prisavslag ved mangelfulle vederlagsaksjer. Ved den nærmere avgrensningen kan det etter mitt syn muligens ha noe for seg å ta utgangspunkt i skillet mellom hovedforpliktelser og biforpliktelser, som er kjent fra obligasjonsretten. Hovedforpliktelsene må alltid regnes med, d.v.s. penger og aksjer. Det samme gjelder mer spesielle biforpliktelser, som f.eks. en konkurranseklausul (til fordel for selgeren). Alminnelige biforpliktelser må normalt holdes utenfor, som typisk tilbyderens forpliktelse til å medvirke ved gjennomføringen av kjøpet. Sistnevnte forpliktelser foreligger gjerne i like stor grad på selgerens side, slik at de uansett kan ses på som vederlag for noe annet enn aksjer (se neste punkt). Utover dette er det vanskelig å gi noen veiledning om avgrensningen.

\subsection{Avgrensning mot vederlag for tilleggsytelser}

I forbindelse med et kjøp av aksjer kan tilbyderen også ha kjøpt noe annet (tilleggsytelser) av den selgende aksjeeieren. Ettersom det bare er vederlag for aksjer som kan få betydning for tilbudsprisen, må man avgrense vederlaget for aksjene mot vederlaget for tilleggsytelsene. ${ }^{64}$ Hvis det ikke er avtalt et særskilt vederlag for aksjene, må avgrensningen som regel skje ved at man først verdsetter samtlige vederlagselementer fra tilbyderen til selgende aksjeeier uavhengig av om disse kan sies å være betaling for aksjer eller tilleggsytelser (se punkt 8 til 10). Deretter finner man frem til og gjør fradrag for verdien av tilleggsytelsene. Bl.a. derfor finner jeg det mer naturlig å behandle avgrensningen mot vederlag for tilleggsytelser senere (se punkt 11).

63 Slik også Børsen, jf. de fleste tilbudsdokumenter.

64 Ordet "vederlag" blir i avhandlingen forbeholdt formuesgoder fra tilbyderen til selgeren av aksjene i målselskapet, mens ordet "ytelse" blir forbeholdt formuesgoder fra selgeren til tilbyderen. 
Her behandles spørsmålet om hvordan verdsettelsen skal skje, d.v.s. hvilke prinsipper som gjelder for verdsettelsen. Behandlingen må begrense seg til prinsippene for de mest praktiske former for vederlag: penger og aksjer (se punkt $8.1 \mathrm{og}$ 8.2). Utover dette har jeg funnet plass til enkelte generelle verdsettelsesprinsipper, som gjelder uavhengig av vederlagets art (se punkt 8.3 til 8.5). I punkt 9 behandles spørsmålet om hvilket tidspunkt, eventuelt hvilken periode, verdsettelsen skal knyttes til.

\subsection{Penger}

\subsubsection{Vederlag og oppgjør i ulik valuta}

Oppgjøret skal skje i penger, jf. vphl. 6-10(6) første pktm. Ordlyden gir ikke noen holdepunkter for at dette må forstås som norske kroner. Ifølge forarbeidene betyr "penger" simpelthen tvungne betalingsmidler eller kreditering av selgende aksjeeiers bank- eller postgirokonto ${ }^{65}$ Børsen har uttalt at oppgjøret kan skje i utenlandsk valuta. ${ }^{66}$ Hvis vederlagets valuta blir lagt til grunn for oppgjøret, er en verdsettelse unødvendig. Her er forutsetningen at vederlagets valuta er en annen enn den som skal bli lagt til grunn for oppgjøret.

Det finnes ingen offisielle kurser på valutamarkedet. Børsen har uttalt at det riktige ved beregning av valutakurs er å foreta en gjennomsnittsberegning av "valutakurser fra ulike kilder." ${ }^{67} \mathrm{Jeg}$ antar at Børsen med dette mener de kurser bankene anvender i sin løpende valutahandel. Slike kurser er imidlertid ikke objektive, fordi de avhenger av partenes forhandlingsposisjon, tilbud og etterspørsel m.v. til enhver tid. I noen grad vil en "gjennomsnittsberegning" kunne avhjelpe manglende objektivitet.

Et alternativ, som kanskje er bedre, er å basere valutakurser på den såkalte WM/Reuters Closing Spot Rates som bygger på ordre og kurser fra banker verden over. Det er kurser herfra som i alminnelighet blir anvendt på de europeiske valutamarkedene, og som av markedets aktører blir ansett som mest riktige og uavhengige. Kursene blir fastsatt hver dag kl 16.00 GMT (17.00 norsk tid) og anses for å gjelde til samme tid neste dag. I Sverige har Aktiemarknadsnemnden ${ }^{68}$ godkjent at valutakurser blir fastsatt med grunnlag i WM/Reuters Closing Spot Rates. ${ }^{69}$

\subsubsection{Betalingsutsettelse. Deponering av pengevederlag}

Hvis tilbyderen er gitt betalingsutsettelse, må vederlaget diskonteres. En beslektet situasjon er der en del av kjøpesummen etter et frivillig tilbud blir deponert til sikkerhet for eventuelle fremtidige garantikrav fra tilbyderen. Også den del av kjøpesummen som blir deponert, må diskonteres hvis det er tilbyderen som skal ha rentene på depotkontoen. Hvis det er selgeren som skal ha rentene, skal det ikke skje en diskontering.

\subsection{Aksjer}

\subsubsection{Notert kurs eller virkelig verdi?}

Verdien av en notert aksje kan fastsettes med grunnlag i notert kurs. Alternativet er selskapets underliggende økonomiske (virkelige) verdier, som kan sies å være selskapets balanse pluss markedets diskonterte forventning til selskapets fremtidige inntjening. I et effektivt marked er notert kurs lik virkelig verdi.

$\begin{array}{ll}65 & \text { Ot. prp. nr. } 53 \text { (1988-1989) s. } 27 . \\ 66 & \text { Oslo Børs (1995) s. } 55 . \\ 67 & \text { Oslo Børs (2000) s. 81. } \\ 68 & \text { Aktiemarknadsnemnden er, noe forenklet sagt, tilbudsmyndighet for svenske selskaper noterte på OMX Nordic Exchange } \\ & \text { Stockholm. } \\ 69 & \text { AMN 2006:35. }\end{array}$


Verdien av en unotert aksje er vanskeligere å fastsette, fordi den ikke omsettes $\mathrm{i}$ et effektivt/likvid marked. Utgangspunktet må vel være selskapets balanse med et rimelig påslag for forventet fremtidig inntjening og med fradrag for en estimert risiko knyttet til aksjens svake likviditet. Alternativt kan verdsettelsen ta utgangspunkt i det materiale (prospekt o.l.) som tilbyderen normalt vil (må) ha forelagt selgeren i forbindelse med avtaleinngåelsen.

\subsubsection{Deponering av vederlagsaksjer}

Også vederlag i aksjer kan tenkes å bli deponert til sikkerhet for tilbyderens fremtidige garantikrav. I Hitec-saken krevde National Oilwell (NOI), som vilkår i det frivillige tilbudet, at de som aksepterte måtte godta at 10 prosent av vederlaget i NOI-aksjer skulle deponeres i ett år fra det tidspunktet tilbudet ble ubetinget. Virkningen av en deponering er at aksjene verken kan omsettes eller pantsettes. Dette representerer etter Nemndens oppfatning "et verdiminus for dem som godtok det frivillige tilbudet, og som NOI må ha anledning til å ta hensyn til i forbindelse med det pliktige tilbudet." Verdiminuset vil dels avhenge av hvor mange aksjer som er deponert, og dels av deponeringens lengde. Nemnden fant at det var uten betydning at aksjene var overført til VPS-kontiene til aksjeeierne i målselskapet. Når det gjelder verdsettelsen av deponerte vederlagsaksjer, sluttet Nemnden seg til Børsens vurdering om at en opsjonsmodell (Black \& Scholes) var riktig å anvende. ${ }^{70}$

\subsubsection{Vederlagsaksjer notert i utlandet}

I de tilfeller vederlagsaksjene er noterte $\mathrm{i}$ et utenlandsk marked, må det foretas en beregning av valutakurs i forbindelse med fastsettelsen av tilbudsprisen. Slik var situasjonen i Hitec-saken, fordi NOI er et selskap notert på New York Stock Exchange. Samme synspunkter som nevnt i punkt 8.1.1 må gjelde.

\subsubsection{Tegningsretter knyttet til vederlagsaksjer}

Det kan være knyttet tegningsretter til vederlagsaksjene. Ofte kan verdien av disse være ubetydelig, slik at det kan være grunn til å avgrense mot den (se punkt 7.3). I en sak for Aktiemarknadsnemnden ble tegningsrettene ansett for å være verd Skr 0,000046 pr. rett. ${ }^{71}$ Men hvis verdien ikke er ubetydelig, må den medregnes f.eks. med grunnlag i Black \& Scholes.

\subsubsection{Salgsopsjoner knyttet til vederlagsaksjer}

En vederlagsaksje kan samtidig være kombinert med en salgsopsjon. Ved Akers oppkjøp av Natural fikk som nevnt Remmereit aksjer i Aker Biomarine kombinert med en opsjon til å selge disse tilbake til Aker for det som ville bli kursen i en planlagt emisjon (se punkt 5.4). En salgsopsjon har en verdi som må få betydning for tilbudsprisen. Verdsettelsen kan skje ut fra Black \& Scholes, binomisk opsjonsteori m.v.

\subsection{Vederlag knyttet til fremtidige forhold}

Ved tidspunktet for fremsettelse av pliktig tilbud kan det være knyttet usikkerhet til om et avtalt vederlag noen gang kommer til å bli betalt, og i tilfelle med hvilken størrelse. Det kan også være knyttet usikkerhet til om et betalt vederlag kommer til å bli tilbakebetalt. Usikkerheten kan skyldes at vederlaget, eventuelt en del av dette, er betinget, og at betingelsen ikke er inntrådt ved fremsettelse av tilbud. I punkt 8.3.1 og 8.3.2 behandles enkelte betingelser som kan skape eller har skapt problemer ved verdsettelsen i praksis. Usikkerheten kan også skyldes at vederlaget er avhengig av andre forhold enn betingelser som ikke er inntrådt ved fremsettelse av tilbud. I punkt 8.3.3 behandles ett slikt forhold, nemlig det at et vederlag kan være knyttet til en fremtidig markedskurs.

$70 \quad$ Oslo Børs (2000) s. 80.

$71 \quad$ AMN 2001:29 s. 1. 


\subsubsection{Alle vederlag er betinget av en underliggende avtale}

Ethvert vederlag kan sies å være betinget, nemlig av at den avtalen om kjøp av aksjer som vederlaget er en del av, blir gjennomført. Hvis det ved fremsettelse av pliktig tilbud er knyttet usikkerhet til om avtalen kommer til å bli gjennomført eller falle bort, kan ikke vederlaget etter avtalen få betydning for tilbudsprisen med sin fulle kroneverdi. Nærliggende er vederlagets (diskonterte) kroneverdi multiplisert med en estimert sannsynlighet for at avtalen blir gjennomført, men muligens må mer avanserte opsjonsmodeller benyttes ved beregningen. Hvis det er knyttet betydelig usikkerhet til om avtalen blir gjennomført, må det være riktig å se bort fra vederlaget etter avtalen ved verdsettelsen.

\subsubsection{En del av vederlaget kan være spesielt betinget}

Det kan også være knyttet (spesielle) betingelser til en bestemt del av vederlaget. Hvis det ved fremsettelse av pliktig tilbud er knyttet usikkerhet til om betingelsen blir oppfylt eller ikke, kan dette skape særlige problemer ved verdsettelsen fordi et pliktig tilbud ikke kan gjøres betinget, jf. vphl. $\$$ 6-10(2).

Et eksempel gir Elkem-saken (se punkt 7.1). Her kunne ikke tilbudsprisen lyde på kr 235 pluss retten til tilleggsvederlag som var betinget av at Orkla kjøpte eller solgte aksjer til en høyere veiet gjennomsnittskurs enn kr 235 i en gitt periode, jf. vphl. \$6-10(2). Retten måtte bli verdsatt. Børsklagenemnden fant at "det ikke er anerkjente teorier eller modeller for verdsettelsen av rettighetene i denne saken. Verdsettelsen må derfor skje på et annet grunnlag, med et nødvendig innslag av skjønn."72 Ved skjønnsutøvelsen tar Nemnden utgangspunkt i selgernes subjektive oppfatning om verdien av den betingede retten, som var kommet til uttrykk i en endringsavtale (se punkt 8.4.1).

\subsubsection{Vederlag knyttet til fremtidig markedskurs}

Vederlaget trenger ikke være fastsatt til noen bestemt pris. I stedet kan det f.eks. være fastsatt til markedskursen på aksjene i målselskapet ved et fremtidig tidspunkt. Hvis dette tidspunktet ennå ikke er kommet ved fremsettelse av pliktig tilbud, må beregningen av tilbudsprisen skje i to ledd: Først må man finne frem til en antatt fremtidig markedskurs (normalt slik denne måtte ha fortonet seg på avtaleeller betalingstidspunktet, se punkt 9.1). For det andre må markedskursen diskonteres.

\subsection{Vederlag uten objektiv verdi}

Ofte går det greit å finne frem til en objektiv verdi (markedsverdi) for vederlagselementene. I andre tilfeller kan dette være vanskelig, som f.eks. i Elkem-saken (se punkt 7.1 og 8.3.2). Dessuten kan det tenkes vederlagselementer uten objektiv verdi i vanlig forstand, som for én selger kan være helt uten økonomisk verdi, mens for en annen ha stor verdi. Et eksempel kan være en konkurranseklausul, der tilbyderen på visse vilkår forplikter seg til ikke å etablere virksomhet i konkurranse med selgeren. Det må uten videre være klart at vederlagselementer uten objektiv verdi kan få betydning for tilbudsprisen, jf. formålet om likebehandling. Spørsmålet er hvordan vederlagselementene skal verdsettes.

\subsubsection{Utgangspunktet om en subjektiv verdsettelse}

Formålet om likebehandling og Nemndens/Børsens praksis tilsier at verdsettelsen som utgangspunkt må være subjektiv, d.v.s. at det er vederlagets verdi for selgeren som er avgjørende. Hvilken verdi dette er, kan tenkes utledet av de ytre omstendighetene ved aksjeervervet. Elkem-saken er illustrerende (selv om denne strengt tatt gjelder verdsettelsen av et vederlag med objektiv verdi). Her var selgernes oppfatning om den betingede retten til tilleggsvederlag kommet til uttrykk i en endringsavtale, som innebar at den betingede retten bortfalt for 30 prosent av aksjene mot et tillegg på kr 1 pr. aksje. Retten ble opprettholdt for de resterende 70 prosent av aksjene, men skulle falle bort hvis den av tilbudsmyndigheten ble verdsatt til mer enn $\mathrm{kr} 1$ pr. aksje. ${ }^{73}$ Herav sluttet Nemnden at selgerne verdsatte retten til kr 1 pr. aksje.

$72 \quad$ Oslo Børs (2005) s. 79.

73 Oslo Børs (2005) s. 70. 


\subsubsection{Unntaksvis må verdsettelsen bero på en konkret vurdering}

Hvis de ytre omstendighetene ikke gir grunnlag for en subjektiv verdsettelse, må verdsettelsen bero på en konkret vurdering der det også må være tillatt å ta i betraktning eventuelle empiriske data.

\subsection{Vederlagsfrie erverv}

\subsubsection{Arv, gave, skifte eller fusjon/fisjon}

Tilbudsplikt inntrer ikke ved erverv i form av arv eller gave, vederlag ved skifte, eller vederlag ved fisjon eller fusjon, jf. vphl. $\mathbb{6} 6-2(1)$. I særlige tilfeller kan imidlertid tilbudsmyndigheten pålegge tilbudsplikt ved slike erverv, jf. $\$ 6-2(2)$. Siden tilbyderen da ikke har avtalt eller betalt et vederlag for aksjene (som er representativt for aksjenes verdi), vil en tilbudspris basert på vphl. \$ 6-10(4) første pktm. være lik null eller i hvert fall uforholdsmessig lav. Dermed kan ikke bestemmelsen komme til anvendelse uten at $\mathbb{S}$ 6-2(2) mister sin realitet. Tilbudsprisen må være basert på $\mathbb{S}$ 6-10(4) annet pktm. om markedskurs, eller muligens utledes av hensynet til minoritetsbeskyttelse og andre reelle hensyn (se punkt 3.1).

Det kan hende tilbyderen har avtalt eller betalt vederlag for aksjer i vederlagsperioden, og at han deretter erverver aksjer vederlagsfritt. Hvis det vederlagsfrie ervervet fører til at tilbudsmyndigheten pålegger tilbudsplikt etter $\mathbb{6}$ 6-2(2), oppstår spørsmålet om den avtalte/betalte prisen, markedsprisen, en ulovfestet pris eller eventuelt den høyeste prisen av disse skal legges til grunn for tilbudsprisen. Verken ordlyden i eller forarbeidene til $\$ 6$-10(4) første pktm. gir noen veiledning. Formålet om likebehandling strekker seg ikke lenger enn til å begrunne en tilbudspris lik et vederlag som faktisk er avtalt eller betalt. Løsningen må anses usikker.

\subsubsection{Erverv der vederlaget er betalt før vederlagsperioden}

Det er muligens slik at et vederlag som er betalt før vederlagsperioden ikke kan få betydning for tilbudsprisen, selv om vederlaget er knyttet til det ervervet som gjør at tilbyderen krysser tilbudspliktgrensen (se punkt 5.2.2). Dette kan i så fall gi opphav til et noe spesielt "vederlagsfritt" erverv. En tilbyder kan før vederlagsperioden ha betalt vederlag for mer enn 1/3, men uten at han blir (reell) eier før seks måneder senere. Hvis han ikke har ervervet aksjer mot vederlag i vederlagsperioden, vil man stå overfor et "vederlagsfritt" erverv. Samme synspunkter som nevnt i forrige punkt må gjelde. 
Dersom vederlaget består av elementer som er utsatt for verdisvingninger, oppstår spørsmålet om hvilket tidspunkt, eventuelt hvilken periode, verdsettelsen skal knyttes til.

\subsection{Hovedregelen om en verdsettelse ved avtale- eller betalingstidspunktet}

Vphl. \$ 6-10 fjerde og femte ledd dreier seg om det høyeste vederlag som er "betalt eller avtalt" i vederlagsperioden. Ordlyden utelukker altså tidligere tidspunkter enn avtaletidspunktet (f.eks. ved fremsettelse av frivillig tilbud) og senere tidspunkter enn betalingstidspunktet (f.eks. ved fremsettelse av pliktig tilbud). Dermed tilsier ordlyden følgende: Hvis vederlaget er avtalt før perioden, må verdsettelsen være knyttet til betalingstidspunktet. Hvis vederlaget er betalt etter perioden, må verdsettelsen være knyttet til avtaletidspunktet. Dersom vederlaget både er avtalt og betalt i vederlagsperioden, kan det synes som om det avgjørende tidspunkt etter ordlyden er når vederlaget er høyest. Hvis aksjekursen har steget etter at avtale ble inngått, må verdsettelsen knyttes til betalingstidspunktet. Hvis aksjekursen har falt, må verdsettelsen knyttes til avtaletidspunktet.

Spørsmålet er ikke omtalt i forarbeidene. Etter direktivets ordlyd kan det virke som om det bare er betalingsalternativet som er relevant, jf. art 5(4) og ordet "paid.” Men dette må sannsynligvis forstås på samme måte som City Code, som har vært et viktig forbilde for direktivet. Etter City Code gjelder bare avtalealternativet. Riktignok er ordet "paid" brukt i regel 9.5 bokstav a. Men i kommentarene står det at "the price paid is the price at which the bargain [...] is struck," jf. nr 2 bokstav a (i). Formålet om likebehandling forutsetter tilsynelatende at verdsettelsen fikseres til enten avtale- eller betalingstidspunktet. For hvis minoritetsaksjeeierne kan velge verdsettelsestidspunkt, vil disse komme bedre ut av det enn selgerne av kontrollposten. Men, slik jeg forstår formålet, er poenget at minoritetsaksjeeierne skal komme minst like godt ut av det som selgerne. Det kan ikke stå i veien for en regel som gjør at minoritetsaksjeeierne kommer bedre ut av $\operatorname{det}^{74}$

I Hitec-saken slo Børsklagenemnden fast at det er "det tidspunktet da tilbyderen ble ubetinget bundet av det frivillige tilbudet, som vil være avgjørende for verdifastsettelsen." 75 At dette tidspunktet skal være avgjørende, følger også av Børsens praksis. ${ }^{76}$ Også de svenske takeover-reglene legger et avtaletidspunkt til grunn, jf. kommentarene til punkt II.10. Hensynet til forutberegnelighet for tilbyder taler for en fiksering av tilbudsprisen, og da helst til avtaletidspunktet.

Etter dette må hovedregelen være slik: Hvis vederlaget er avtalt før vederlagsperioden, skal verdsettelsen være knyttet til betalingstidspunktet. Hvis vederlaget er avtalt i vederlagsperioden, skal verdsettelsen være knyttet til avtaletidspunktet.

\subsection{Særlig om verdsettelsestidspunktet for vederlag etter frivillige tilbud}

Etter mitt syn er vederlaget etter et frivillig tilbud å anse som "avtalt" ved den enkelte aksept (se punkt 6.1.3). Denne regelen har $\mathrm{i}$ alle fall den betydning at vederlag som er akseptert før vederlagsperioden, ikke kan få betydning for tilbudsprisen. I denne forstand er imidlertid regelen uten særlig praktisk verdi, fordi vederlaget etter et frivillig tilbud er det samme for alle aksjeeierne, slik at tilbudsprisen uansett blir basert på dette vederlaget som av enkelte selgere vil være akseptert i vederlagsperioden. Regelen om at vederlaget er avtalt ved den enkelte aksept, kan imidlertid tenkes å ha praktisk verdi hvis den kan bli lagt til grunn for verdsettelsen. For da vil det vederlaget som er knyttet til det aksepttidspunktet vederlaget er verdt mest, måtte bli lagt til grunn for tilbudsprisen. Praksis fra Børsklagenemnden og Børsen trekker imidlertid i retning av at verdsettelsen skal være knyttet til det tidspunktet tilbudet ble

\footnotetext{
74 Børsen er muligens av en annen oppfatning når det gjelder formålets rettskildemessige relevans, jf. Oslo Børs (2006) s. 72.

$75 \quad$ Oslo Børs (2000) s. 85 flg.

76 Se f.eks. tilbudsdokumenter Wenaas/Kansas og Axis/Shield.
} 
ubetinget. ${ }^{77}$ I prinsippet kan man tenke seg at vederlaget kan være avtalt ved den enkelte aksept i forhold til vederlagsperioden, mens det er avtalt ved inntreden av betingelsene i forhold til verdsettelsen. Men symmetrihensyn taler mot en slik løsning. Uansett kan det ikke være slik at verdsettelsen avhenger av inntreden av potestative betingelser, men grensen mellom potestative og kasuelle betingelser er vanskelig å trekke. Etter dette må konklusjonen være at vederlaget etter et frivillig tilbud er avtalt ved den enkelte aksept også i forhold til verdsettelsen.

\subsection{Vederlagsperioder for vederlag særlig utsatt for verdisvingninger}

I mange tilfeller gir en verdsettelse ved et bestemt tidspunkt et godt resultat. F.eks. kan det til vederlagsaksjer være knyttet tegningsretter. Slike retter kan få betydning for tilbudsprisen hvis de foreligger på verdsettelsestidspunktet, men ikke hvis de blir utstedt senere. ${ }^{78} \mathrm{I}$ andre tilfeller kan det åpenbart falle uheldig ut å knytte verdsettelsen til et bestemt tidspunkt. Felles for disse tilfellene er at det dreier seg om vederlag som er scerlig utsatt for verdisvingninger, typisk aksjer og eventuelt utenlandsk valuta. Når det gjelder aksjer spesielt, kan dessuten svingningene i noen grad være påvirket av tilbyderen som kan ha interesse av at kursen blir så lav som mulig.

\subsubsection{Aksjer}

For å unngå en tilfeldig verdsettelse og muligheten for manipulasjon av kursen på vederlagsaksjer, har Børsen i praksis fastsatt tilbudsprisen på bakgrunn av en volumveid aksjekurs over en periode på flere dager før avtaletidspunktet. Børsklagenemnden har stilt seg bak dette. ${ }^{79}$ Jo større mulighet for tilfeldig verdsettelse og manipulasjon, desto lenger bør perioden være. Graden av tilfeldig verdsettelse og manipulasjonsmulighet avhenger av aksjens likviditet og volatilitet. Herav følger at jo svakere likviditet og større volatilitet, desto lenger bør perioden være. Dessuten kan et eventuelt derivatmarked gi indikasjoner på muligheten for kursmanipulasjon.

\subsubsection{Utenlandsk valuta}

For å unngå en tilfeldig verdsettelse av utenlandsk valuta, har Børsen i praksis foretatt en gjennomsnittsberegning av valutakurser $\mathrm{i}$ en "femdagersperiode forut for oppgjør." 80 Det at utgangspunktet for beregning av perioden skal være "oppgjør," må være riktig hvis vederlaget er avtalt før vederlagsperioden. Ellers må utgangspunktet være avtaletidspunktet (se punkt 9.1). Uansett kan man diskutere om det er nødvendig med en verdsettelsesperiode, dersom valutaen fastsettes med grunnlag i WM/Reuters Closing Spot Rates (se punkt 8.1.1).

\footnotetext{
77 Oslo Børs (2000) s. 85 flg.

78 Senere utstedte tegningsretter er uansett ikke vederlag for aksjer. Slik også Oslo Børs (1999) s. 68.

79 Oslo Børs (2000) s. 79 og 80.

$80 \quad$ Oslo Børs (2000) s. 81.
} 
Etter at et vederlag er avtalt eller betalt i vederlagsperioden kan det tenkes at partene blir enige om å øke eller redusere vederlaget for aksjene. Spørsmålet er om tilbudsprisen skal tilsvare opprinnelig eller endret vederlag. Det forutsettes her for enkelhets skyld at både opprinnelig og endret vederlag er høyere enn noe annet vederlag tilbyderen har avtalt eller betalt i vederlagsperioden.

Når først avtale er inngått skal det formodentlig litt til for at tilbyderen godtar en vederlagsøkning, og at selgeren godtar en vederlagsreduksjon. I praksis antar jeg derfor at en "vederlagsøkning” ofte henger sammen med at selgeren påtar seg å yte noe mer enn de aksjene som det opprinnelige vederlaget var knyttet til, mens en "vederlagsreduksjon" henger sammen med at tilbyderen påtar seg noe mer. Hvis dette er tilfellet, kan naturligvis ikke "vederlagsendringen" få noen betydning for tilbudsprisen (se punkt 11). Forutsetningen her er at opprinnelig og endret vederlag er knyttet til samme aksje og bare til den.

\subsection{Avtalt vederlagsøkning}

\subsubsection{Før utløsning av tilbudsplikt}

Hvis en avtale om vederlagsøkning finner sted før utløsning av tilbudsplikt (altså i seksmånedersperioden), beror spørsmålet på en fortolkning av vphl. $\mathbb{S} 6-10(4)$ første pktm. Uttrykket "vederlag tilbyderen har avtalt" kan bety vederlag tilbyderen faktisk er forpliktet til å betale, d.v.s. det økte vederlaget. Men uttrykket kan også bety vederlag tilbyderen på et eller annet tidspunkt har bundet seg til å betale, d.v.s. både det opprinnelige og det økte vederlaget. Men ettersom tilbudsprisen skal tilsvare "det høyeste" av disse, fører også dette alternativet til at tilbudsprisen skal tilsvare det økte vederlaget. Ordlyden tilsier altså at tilbudsprisen skal tilsvare det økte vederlaget. I samme retning trekker formålet med reglene, som må være å sikre faktisk betalt kontrollpremie. Konklusjonen er at tilbudsprisen skal tilsvare det økte vederlaget.

\subsubsection{Etter utløsning av tilbudsplikt}

Hvis en avtale om vederlagsøkning finner sted etter utløsning av tilbudsplikt, men før utløpet av tilbudsperioden, beror spørsmålet på en fortolkning av vphl. \$ 6-10(5) første pktm. Etter ordlyden er det avgjørende om tilbyderen har avtalt eller betalt "høyere vederlag enn tilbudsprisen." En vederlagsøkning som skjer etter fremsettelse av tilbud, er høyere enn tilbudsprisen (som er basert på det opprinnelige vederlaget). Dersom vederlagsøkningen skjer før fremsettelse av tilbud, foreligger det strengt tatt ikke noen tilbudspris som det økte vederlaget kan være høyere enn. Men ettersom tilbudsprisen loven her sikter til skal tilsvare det opprinnelige vederlaget etter $\mathbb{\$} 6-10(4)$ første pktm., er det rimelig å forstå ordet "tilbudspris" som det opprinnelige vederlaget. Dermed tilsier ordlyden at tilbudsprisen skal tilsvare det økte vederlaget, som også må være konklusjonen ettersom formålet trekker i samme retning.

En avtale om vederlagsøkning inngått etter tilbudsperioden, kan ikke få betydning for tilbudsprisen. Verdipapirhandelloven har ingen regler om etterkompensasjon, selv om dette i noen grad åpner for omgåelser (se punkt 5.4).

\subsection{Avtalt vederlagsreduksjon}

\subsubsection{Før utløsning av tilbudsplikt}

Også her er utgangspunktet vphl. \$6-10(4) første pktm. og uttrykket "vederlag tilbyderen har avtalt." Uttrykket kan som nevnt bety vederlag tilbyderen faktisk er forpliktet til å betale, d.v.s. redusert vederlag. Det kan også bety vederlag tilbyderen på et eller annet tidspunkt har bundet seg til å betale, d.v.s. både opprinnelig og redusert vederlag. Men ettersom tilbudsprisen skal tilsvare "det høyeste" av disse, fører 
dette alternativet til at tilbudsprisen skal tilsvare opprinnelig vederlag. Til forskjell fra situasjonen ved en vederlagsøkning trekker altså ikke ordlyden i noen bestemt retning ved en vederlagsreduksjon.

Formålet med reglene er å sikre faktisk betalt kontrollpremie. Dette blir oppfylt uavhengig av om tilbudsprisen settes lik opprinnelig eller redusert vederlag, og gir derfor ingen veiledning i denne sammenheng. En annen sak er at en tilbudspris lik opprinnelig vederlag sikrer minoritetsaksjeeierne mer enn faktisk betalt kontrollpremie. Etter dette må spørsmålet bero på en avveiing av reelle hensyn. Omgåelseshensyn trekker i retning av en tilbudspris lik det opprinnelige vederlaget. For hvis et redusert vederlag kan få betydning for tilbudsprisen, åpner dette for konstruksjoner der tilbyderen påtar seg forpliktelser som ikke er så lett synlige mot en reduksjon av vederlaget. På den annen side, det er simpelthen ikke rimelig å la tilbudsprisen tilsvare opprinnelig vederlag.

Konklusjonen må helst være at tilbudsprisen skal tilsvare redusert vederlag.

\subsubsection{Etter utløsning av tilbudsplikt}

Hvis en avtale om vederlagsreduksjon finner sted etter utløsning av tilbudsplikt, men før utløpet av tilbudsperioden, beror spørsmålet på en fortolkning av vphl. $\$$ 6-10(5) første pktm. Etter ordlyden er det avgjørende om tilbyderen har avtalt eller betalt "høyere vederlag enn tilbudsprisen." En avtale om vederlagsreduksjon kan ikke gjelde et vederlag som er høyere enn tilbudsprisen, fordi tilbudsprisen er basert på det opprinnelige vederlaget. Ordlyden er altså et argument for at tilbudsprisen skal tilsvare opprinnelig vederlag.

Dersom en vederlagsreduksjon finner sted før fremsettelse av pliktig tilbud, trekker rimelighetshensyn i retning av at tilbudsprisen skal tilsvare redusert vederlag. Dette ble også uttalt av Børsklagenemnden i Elkem-saken, som nettopp dreide seg om en endringsavtale inngått etter utløsning av tilbudsplikt, men før fremsettelse av tilbud. ${ }^{81}$ Videre uttalte Nemnden at "så lenge den reviderte avtalen har full realitet for avtalens uavhengige parter (herunder selgerne av en kontrollpost som i denne saken), kan det ikke legges til grunn at loven stenger for endring av en tidligere inngått avtale med virkning for tilbudsprisen." Etter mitt syn kan ikke dette være riktig. Ordlyden og omgåelseshensyn (se forrige punkt) står mot rimelighetshensyn. Dermed må konklusjonen være at "loven stenger for endring” i den forstand at tilbudsprisen skal tilsvare opprinnelig vederlag.

Dersom en vederlagsreduksjon finner sted etter fremsettelse av pliktig tilbud, trekker reelle hensyn i retning av at tilbudsprisen skal tilsvare opprinnelig vederlag. Det kan anføres at markedet innretter seg etter tilbudet med de følger dette kan få for aksjekursen. Dessuten har det vært hevdet at tilbyderen er avtalerettslig forpliktet etter fremsettelse av tilbud. ${ }^{82}$ Konklusjonen er klart nok at tilbudsprisen skal tilsvare opprinnelig vederlag.

\subsection{Vederlagsendringer som følge av mislighold o.I.}

Etter at et vederlag er avtalt eller betalt i vederlagsperioden kan det tenkes at vederlaget blir endret som følge av mislighold. En vederlagsreduksjon (prisavslag) må skyldes en mangel ved aksjene i målselskapet, mens en vederlagsøkning (erstatning) må skyldes en mangel ved vederlaget, typisk en mangel ved vederlagsaksjer. Spørsmålet er om tilbudsprisen skal tilsvare opprinnelig eller endret vederlag.

Vphl. $\$ 6-10 fjerde og femte ledd dreier seg om vederlag som er "avtalt." Dette kan som nevnt bety vederlag tilbyderen faktisk er forpliktet til å betale, d.v.s. endret vederlag, men også vederlag tilbyderen på et eller annet tidspunkt har bundet seg til å betale, det vil her si opprinnelig vederlag. Ordlyden gir ingen veiledning. Rettskildesituasjonen er ellers som nevnt i punkt 10.1 og 10.2. Dette skulle tilsi at en vederlagsøkning i vederlagsperioden kan få betydning for tilbudsprisen.

$81 \quad$ Oslo Børs (2005) s.72, 77 og 78.

82 Se f.eks. Børsens uttalelser gjengitt i Oslo Børs (2006) s. 72. 
Det samme gjelder en vederlagsreduksjon, selv om denne skjer etter utløsning av tilbudsplikt (men før utløpet av tilbudsperioden), fordi ordlyden her er nøytral i motsetning til for avtalt vederlagsreduksjon.

Det som her er blitt sagt om mislighold, må gjelde tilsvarende for andre revisjonsgrunnlag som f.eks. avtaleloven $\mathbb{3 6}$. 


\section{AVGRENSNINGER VED KJØP AV TILLEGGSYTELSER}

Vphl. \$6-10(4) sier ikke noe om hva vederlaget må være betalt for, men det må naturligvis være betalt for aksjer som kan utløse tilbudsplikt. I forbindelse med et kjøp av aksjer kan imidlertid tilbyderen også ha kjøpt noe annet (tilleggsytelser) av den selgende aksjeeieren. Dermed må man avgrense vederlaget for aksjene mot vederlaget for tilleggsytelser (se punkt 11.1). Men i prinsippet er første spørsmål om et kjøp av aksjer er kombinert med kjøp av tilleggsytelser. Spørsmålet er ikke bare av faktisk art. For det kan være knyttet rettslig tvil til grensen mellom eiendomsrett til aksjer og tilleggsytelser, selv om dette ikke er vanlig. Og for øvrig er det ikke alltid like åpenbart at et kjøp også omfatter tilleggsytelser. I neste punkt skal jeg se på enkelte slike tvilstilfeller.

\subsection{Avgrensning av eiendomsrett til aksjer og tilleggsytelser}

\subsubsection{Kjøps- og salgsopsjoner. Reelt erverv av aksjer}

Når det gjelder kjøpsopsjoner følger det av forarbeidene at markedsmessig opsjonspremie ikke er en del av vederlaget for eiendomsrett til aksjer. Begrunnelsen er at "utsteder av opsjonen påtar seg en risiko ved å frasi seg muligheten til å velge et eventuelt høyere bud og ved ikke å kunne selge aksjen i opsjonsperioden." ${ }^{83}$ Eller omvendt, markedsmessig opsjonspremie er betaling for en tilleggsytelse i form av den særlige retten opsjonen gir innehaveren. Innløsningsprisen og eventuell ikke-markedsmessig opsjonspremie, d.v.s. den delen av "opsjonspremien" som overstiger markedsmessig premie, er en del av vederlaget for eiendomsrett til aksjer.

Heller ikke er markedsmessig premie for salgsopsjoner en del av vederlaget for eiendomsrett til aksjer. En slik premie er vederlag for retten til å selge aksjer til utstederen. Dermed er det snarere tvert i mot en nærliggende tanke at opsjonspremien må komme til fradrag i innløsningsprisen, fordi den da beregnede summen tilsvarer utstederens totale kostnad i forbindelse med aksjeervervet. Men et slik fradrag må være uaktuelt, fordi markedsmessig premie er betaling for den særlige retten som opsjonen gir innehaveren. Eller omvendt, den særlige salgsretten er vederlag for en tilleggsytelse i form av markedsmessig opsjonspremie. Mer tvilsomt er det etter mitt syn om ikke-markedsmessig opsjonspremie må komme til fradrag i innløsningsprisen.

Det kan hende at inngålse av en opsjonsavtale i realiteten er å anse som et erverv av eiendomsrett til aksjene. I så fall er "opsjonspremien” etter en "kjøpsopsjon” en del av vederlaget for eiendomsrett til aksjer, ${ }^{84}$ mens "opsjonspremien" etter en "salgsopsjon" etter mitt syn må komme til fradrag i innløsningsprisen. ${ }^{85}$

\subsubsection{Hurtigsvarsrente i frivillig tilbud}

Det hender at tilbyderen i frivillig tilbud gir rentekompensasjon fra enten aksepttidspunktet eller et "proforma oppgjørstidspunkt" eller utløpet av tilbudsperioden, og frem til oppgjør skjer (hurtigsvarsrente). ${ }^{86}$ Ifølge forarbeidene skal slik rentekompensasjon "ikke anses som del av vederlaget dersom den utgjør en reell markedsmessig kompensasjon for likviditetsavsavn fra det tidspunkt oppgjør ville blitt gitt dersom det var tatt forbehold for tilbudet, og frem til tidspunktet for oppgjør." ${ }^{87}$ Man kan si det slik at markedsrente er betaling for en tilleggsytelse i form av likviditetsavsavn. ${ }^{88}$

\footnotetext{
$83 \quad$ NOU 1996: 2 s. 122.

84 Ot. prp. nr. 29 (1996-1997) s. 70.

85 Ved opsjoner med finansielt oppgjør er verken opsjonspremien eller innløsingsprisen vederlag for eiendomsrett til aksjer.

86 Hurtigsvarsrente i pliktig tilbud er sannsynligvis ikke tillatt, fordi en slik rente vil "uthule den beskyttelse som ligger i reglene om tilbudsperioden," jf. NOU 1996:2 s. 122.

$87 \quad$ NOU 1996:2 s. 122.

88 Se også pliktig tilbudsdokument Merita-Nordbanken/Kreditkassen av 8.1.2001, som ble godkjent av Børsen.
} 


\subsubsection{Aksjer kjøpt på termin}

Tilbyderen kan ha kjøpt aksjer på termin. Et slikt kjøp innebærer at både kjøper og selger har rett og plikt til å gjennomføre den avtalte transaksjonen på et fremtidig tidspunkt (kjøp med utsatt oppgjør). Ved slike kjøp vil en del av kjøpesummen realøkonomisk være betalt for en tilleggsytelse i form av en rentefordel, slik at denne delen må holdes utenfor verdsettelsen. I samme retning trekker juridisk litteratur. ${ }^{89}$ Det kan muligens hevdes at en (annen) del av vederlaget er betalt for selgerens kredittrisiko.

\subsection{Avgrensning av vederlag for aksjer og tilleggsytelser}

Hvis et kjøp av aksjer er kombinert med kjøp av tilleggsytelser, må man avgrense vederlaget for aksjene mot vederlaget for tilleggsytelsene. Ved kjøp av aksjer i regulert marked byr ikke avgrensningen av vederlaget på problemer, fordi det normalt bare er snakk om en tilleggsytelse i form av en meglertjeneste mot fast kurtasje. Kjøp av aksjer utenfor marked kan imidlertid være kombinert med erverv av andre tilleggsytelser, f.eks. en fast eiendom eller en tjeneste typisk i form av selgerens forpliktelse til å arbeide for målselskapet en periode. Hvis det er avtalt et særskilt vederlag for aksjene, vil normalt dette bli godkjent av tilbudsmyndigheten som grunnlag for tilbudsprisen. Men tilbudsmyndigheten må foreta en nærmere vurdering ved mistanke om et misforhold mellom vederlaget for aksjene og tilleggsytelsene. I "verste" fall kan dette skyldes at partene bevisst har nedjustert vederlaget for aksjene med sikte på en tilsvarende lav tilbudspris. Avgrensningen byr imidlertid på størst problemer i praksis hvis det ikke er avtalt et særskilt vederlag for aksjene. Slik vil det ofte være ved fusjon, som kan utløse tilbudsplikt der et fusjonert selskap blir eier av mer enn 1/3 av aksjene i et tredje selskap (A), fordi det overdragende selskapet eier aksjer i A, jf. vphl. $\mathbb{S} 6-2(1) \mathrm{nr} 3$. Aksjene i A er en del av de rettigheter, eiendeler og forpliktelser som overføres, og vil som regel ikke være særskilt priset.

\subsubsection{Positiv avgrensning av vederlag for aksjer}

Når man skal skille fra hverandre vederlag for aksjene og vederlag for tilleggsytelser, kan man i prinsippet gå frem på to måter. En mulighet er å ta utgangspunkt i aksjenes verdi (noterte kurs) på verdsettelsestidspunktet for vederlaget (se punkt 9), for deretter å beregne en kontrollpremie teoretisk. Ved en slik beregning vil det være naturlig å se hen til erfaringsbaserte premier ved oppkjøp av norske noterte selskaper justert for eventuelle særlige forhold ved det konkrete målselskap. En slik positiv avgrensning av vederlaget for aksjene må imidlertid, i hvert fall som et utgangspunkt, være utelukket. For etter ordlyden i vphl. $\$$ 6-10(4) første pktm., forarbeidene og formålet er det faktisk avtalt eller betalt kontrollpremie minoritetsaksjeeierne har krav på.

\subsubsection{Negativ avgrensning mot vederlag for tilleggsytelser}

En annen mulighet er å ta utgangspunkt i verdien av samtlige vederlagselementer fra tilbyderen til selgende aksjeeier uavhengig av om disse kan sies å være betaling for aksjer eller tilleggsytelser. Deretter finner man frem til verdien av tilleggsytelsene etter samme prinsipper og tidspunkt som vederlagselementene fra tilbyderen (se punkt 8 til 10). Verdien av tilleggsytelsene trekkes så fra verdien av samtlige vederlagselementer. Hvis f.eks. samlet vederlag er verd 1000 og tilleggsytelsene 600, skulle dette tilsi at tilbyderen har betalt 400 for aksjene. I juridisk litteratur er en slik negativ avgrensning av vederlaget angitt som eksempel på hvordan tilbudsmyndigheten kan gå frem ved godkjenning av tilbudspris. ${ }^{90}$

Avgrensningen gir en fornuftig løsning dersom tilbyderen for tilleggsytelsene faktisk har betalt en verdi som følger av de alminnelige verdsettelsesprinsippene (markedsverdi, subjektiv verdi o.s.v.). Slik vil det naturligvis være ved standardiserte ytelser, som noterte opsjoner og avsavnsrenter. Ellers kan det hende at tilbyderen enten har gjort et godt eller dårlig kjøp (henholdsvis til under og over verdi). Sett

89 Bechmann (2002) s. 335.

90 Bechmann (2002) s. 331. 
at tilbyderen i eksempelet ovenfor gjorde et godt kjøp av tilleggsytelsene, som han betalte 500 for. Han har i så fall betalt 500 for aksjene. Hvis han gjorde et dårlig kjøp, f.eks. etter en kalkulasjonsfeil, og betalte 700 for tilleggsytelsene, har han betalt 300 for aksjene. Hvorvidt kjøpet er godt eller dårlig må ha betydning for tilbudsprisen, fordi det er faktisk avtalt eller betalt vederlag som kan få betydning for tilbudsprisen.

Spørsmålet om vederlag er knyttet til aksjer eller tilleggsytelser kommer ofte opp i praksis. Et eksempel gir National Oilwells (NOI) kjøp av Hydralift i 1999. Oppkjøpet skjedde i tre ledd: Først sikret NOI seg opsjon på storeier og styreformann Bjarne Skeies 22,8 prosent av aksjene, deretter ble det fremsatt et frivillig tilbud som ble fulgt opp av et pliktig. Tilbudsprisen var kr 55 pr. aksje. Men det ble reist spørsmål ved om Skeie fikk mer. Samtidig med aksjene solgte han nemlig et næringsbygg til NOI for (på papiret) kr 118 mill. En eiendomsmegler iMarkedet.no snakket med anslo verdien til kr 70 mill. ${ }^{11}$ I så fall kan det argumenteres med at kun kr 70 mill skal holdes ute fra det samlede vederlaget, slik at kr 48 mill er vederlag for aksjer. I tillegg til eiendomssalget inngikk Skeie en avtale med NOI, der Skeie forpliktet seg til å yte nærmere bestemte tjenester for NOI mot kr 3 mill årlig i ti år. Det kan være vanskelig å finne ut av om det er noen realitet i en slik avtale. ${ }^{92}$

Noen av disse problemene kan finne sin løsning ved at det i tilbudsdokumentet særskilt skal angis tilbudsprisen, og hvilken metode som er brukt for å fastsette den, jf. vphl. \$6-13(2) nr. 5. Dessuten kan tilbudsmyndigheten kreve opplysninger fra verdipapirforetak, selskap og personer som kan ha betydning for spørsmål som omfattes av kapittel 6, herunder tilbudsprisen, jf. \$15-4. Men det kan likevel være vanskelig for tilbudsmyndigheten å gjennomskue partenes arrangementer. For Storbritannias del har man søkt å løse problemene ved et forbud mot "Special deals with favourable conditions" etter at tilbud er fremsatt, eller etter at det er rimelig klart at et tilbud vil bli fremsatt, jf. City Code regel 16 . En form for spesialavtale er "to enter into a transaction to dispose of some of the offeree company's assets to him for a favourable price." I mangel av holdepunkter kan muligens vphl. $\$$ 6-10(4) annet pktm. om markedskurs benyttes som grunnlag for tilbudsprisen.

91 Slettan (1999), Berglihn (2002).

92 Se også Oslo Børs (2000) s. 81, der Fred Olsen Energys, samtidig med kjøp av aksjer i Navis fra R\&B Falcon, kjøpte en managementavtale for boreskipet Navis Explorer fra R\&B. 
Etter allmennaksjeloven $\mathbb{S}$ 4-1 kan et selskap bestemme at det skal ha flere aksjeklasser med ulike rettigheter, typisk hva gjelder stemmerett og utbytterett. Ulike aksjeklasser kan ha ulik markedsverdi. I så fall kan det reises spørsmål ved om tilbudsprisen er forskjellig for ulike aksjeklasser, og i tilfelle hvor store forskjellene kan være (se punkt 12.1). Tilsvarende spørsmål kan oppstå der målselskapet også har unoterte aksjer (se punkt 12.2). Det er få selskaper på Oslo Børs som har flere aksjeklasser eller unoterte aksjer, slik at spørsmålene ikke er så praktisk viktige. ${ }^{93}$

\subsection{Målselskapet har flere aksjeklasser}

\subsubsection{Om prisen er forskjellig for ulike aksjeklasser}

Loven legger opp til at det skal være én og samme tilbudspris for alle aksjene, jf. vphl. $\$$ 6-10 fjerde og femte ledd. Spørsmålet er ikke omtalt i forarbeidene til vphl. 2007 eller vphl 1997. Forut for endringsloven av 1989 uttalte departementet at "i de tilfelle hvor tilbudsplikten omfatter verdipapirer med f.eks. begrenset stemmerett som har en avvikende markedsverdi fra full stemmerett, må tilbudsprisen for disse fastsettes slik at det gis et sammenlignbart vederlag med det som skal gis iht hovedregelen om tilbudsplikt." ${ } 94$ Dermed trekker forarbeidene i retning av at tilbudsprisen kan være forskjellig for ulike aksjeklasser, hvis aksjeklassene har avvikende markedsverdi. ${ }^{95}$

Direktivet bestemmer at tilbudsprisen skal være den høyeste prisen betalt for "the same securities," jf. art 5(4) første pktm. Det sier imidlertid ingenting om prisen for andre securities, som tilbudet skal omfatte etter art 5(1) første pktm. Meningen må nødvendigvis være at tilbudsprisen for slike andre "securities" kan være en annen. Børsen har godkjent både lavere og høyere tilbudspris for aksjer med begrenset stemmevekt. ${ }^{96}$ City Code regel 14 gjelder "where there is more than one class of share capital." Da skal tilbyderen fremme "a comparable offer," jf. 14.1. Ifølge de svenske takeover-reglene kan tilbyderen "ge innehavare av aktier med icke identiska villkor erbjudanden som skiljer sig åt i fråga om vederlagets form och värde,” jf. punkt II.9 første ledd. I samme retning trekker juridisk litteratur. ${ }^{97}$

Etter dette må konklusjonen være at tilbudsprisen kan være forskjellig for aksjeklasser med ulike rettigheter og avvikende markedsverdi.

\subsubsection{Fastsettelse av prisen}

Ifølge forarbeidene må tilbudsprisen fastsettes slik at det gis et "sammenlignbart vederlag med det som skal gis iht hovedregelen om tilbudsplikt." ${ }^{98}$ Dette gir lite veiledning. Der tilbudsplikt er utløst etter en-bloc kjøp må utgangspunktet være at den samme prosentmessige kontrollpremie skal tilbys alle aksjeeiere på aksjenes markedsverdi knyttet til tidspunktet rett før oppkjøpet ble kjent i markedet. Slik også de svenske takeover-reglene punkt II.9. Sett at en tilbyder betaler kr 120 for aksjer med full stemmevekt som utløser tilbudsplikt, premien er 20 prosent, og verdiforholdet mellom aksjer med full stemmevekt og aksjer med begrenset stemmevekt er 100/90 rett før oppkjøpet ble kjent. I et slikt tilfelle er tilbudsprisen kr 108 for aksjer med begrenset stemmevekt.

93 Tilbudet skal omfatte alle selskapets aksjer, jf. vphl. § 6-10(2). Det trenger ikke omfatte opsjoner, konvertible obligasjoner eller andre former for tegningsretter som måtte ha ført til en annen tilbudspris enn for aksjer.

94 Ot. prp. nr. 53 (1988-1989) s. 22.

95 Når det gjelder aksjeklasser med ulik stemmerett spesielt, finnes det imidlertid enkelte argumenter i motsatt retning i komitéens innstilling, jf. Innst. O. nr. 91 (1988-1989) s. 12. Men disse er mindre viktige etter mitt syn.

96 Se hhv. f.eks. tilbudsdokument 22.09.97 (Amersham/Nycomed) og tilbudsdokument 2.3.06 (Seadrill/Smedvig).

97 Bechmann (2002) s. 323 og 329.

98 Ot. prp. nr. 53 (1988-1989) s. 26. 
Hvis verdiforholdet var 100/110, er tilbudsprisen for aksjer med begrenset stemmevekt kr $132 .{ }^{99} \mathrm{De}$ svenske takeover-reglene punkt II.9 gjør unntak hvis "särskilda skäl motiverar olika premier," som henger sammen med at "förhållandena skiljer sig dock alltför mycket från fall till fall för att denna regel alltid skall kunna tillämpas strikt," jf. kommentarene.

Der tilbudsplikt er utløst etter frivillig tilbud må utgangspunktet være at den samme prosentmessige kontrollpremie skal tilbys alle aksjeeiere på aksjenes markedsverdi knyttet til tidspunktet rett før tilbudet ble kjent i markedet. Annerledes ved gradvise kjøp i markedet fordi det her ikke er betalt noen kontrollpremie. Utgangspunktet må muligens tas i kursforholdet ved utløsning av tilbudsplikt. Men det må tas i hvert fall ett forbehold, og det gjelder for aksjeklasser med ulik stemmerett. Oppkjøperen har normalt konsentrert seg om kjøp av aksjer med full stemmevekt. Dermed vil hans (og andres) etterspørsel etter slike aksjer gjerne ha løftet kursen på aksjene forut for utløsning av tilbudsplikt uten at kursen på aksjer med begrenset eller uten stemmevekt er blitt løftet tilsvarende. For aksjeklasser med ulik stemmerett kan det dermed ikke være riktig å bygge på kursforholdet ved utløsning av tilbudsplikt, men på et volumveid kursforhold over en periode på flere dager, kanskje måneder, før utløsning av tilbudsplikt. Slik også City Code regel 14.1 og note nr. 1 andre avsnitt. Som ellers kan man si at det vesentligste må være at tilbyderen tilbyr en pris som er "innenfor en forsvarlig ramme" i forhold til vphl. \$ 6-10 fjerde ledd. Eller som det heter i kommentarene til de svenske takeover-reglene punkt II.9: "Varje innehavarkategori bör ges en rättvis och rimlig behandling."

\subsection{Målselskapet har unoterte aksjer}

\subsubsection{Om prisen er forskjellig for noterte og unoterte aksjer}

Loven legger opp til at det skal være én og samme tilbudspris, jf. vphl. $\$$ 6-10 fjerde og femte ledd. Forarbeidene behandler ikke spørsmålet om tilbudspris for unoterte aksjer. Direktivet har bare regler om tilbudspris for "the same securities," jf. art 5(4) første pktm. Dette uttrykket sikter formodentlig til arten av de finansielle instrumentene, og ikke til om de er noterte eller unoterte. Etter City Code regel 14 note nr. 1 tredje avsnitt kan tilbudsprisen for noterte og unoterte aksjer være forskjellig. I samme retning trekker de svenske takeover-reglene i punkt II.9 og rimelighetshensyn Konklusjonen er at tilbudsprisen for noterte og unoterte aksjer kan være forskjellig.

\subsubsection{Fastsettelse av prisen}

City Code angir bare en metode for fastsettelse av tilbudspris for noterte aksjer. Dersom tilbudet skal omfatte unoterte aksjer heter det: "the ratio of the offer values must be justified to the Panel in advance," jf. regel 14.1 og note nr. 1 tredje avsnitt. Utgangspunktene må være som nevnt i punkt 12.1.2, d.v.s. at samme prosentmessige kontrollpremie skal tilbys alle aksjeeierne på aksjenes markedsverdi. Det er imidlertid vanskelig å fastsette verdien på unoterte aksjer, fordi det unoterte markedet ikke er effektivt. Dermed strander muligens en rettslig analyse ved en regel om at tilbudsprisen for unoterte aksjer må bero på en konkret vurdering og være forsvarlig.

99 Unntaksvis har aksjer med begrenset stemmevekt høyere markedsverdi enn aksjer med full stemmevekt, f.eks. fordi erverv av sistnevnte aksjer er konsesjonsbelagt. 
Etter at tilbyderen har avtalt det høyeste vederlag og frem til oppgiøret i det pliktige tilbudet er gjennomført, kan målselskapet foreta endringer i dets kapital og/eller pålydende. Slike endringer kan føre til at aksjene er mindre eller mer verd ved oppgjøret enn de ville ha vært verd uten endringene. Hvis aksjene er mindre verd, er spørsmålet om endringene kan føre til at tilbudsprisen (minsteprisen) er lavere enn det høyeste vederlag (se punkt 13.1). ${ }^{100}$ Hvis aksjene er mer verd, er spørsmålet om tilbudsprisen er høyere (se punkt 13.2).

\subsection{Om kapitalendringer m.v. kan føre til lavere tilbudspris}

Tilbudsprisen skal være "minst like høy" som det høyeste vederlag, jf. vphl. $\$$ 6-10 fjerde og femte ledd. Etter ordlyden er etterfølgende kapitalendringer uten betydning, og er således et argument mot en lavere tilbudspris ved kapitalendringer.

Direktivet inneholder ikke regler om justering av tilbudspris ved etterfølgende kapitalendringer. I forarbeidene heter det imidlertid: "Departementet slutter seg til Oslo Børs’ vurdering av at tilbudsprisen skal korrigeres for endringer i aksjekapitalen som f.eks. nedsettelse, fondsemisjon mv., i samsvar med det som følger av gjeldende regler." ${ }^{101}$ Børsens høring til utvalgets lovforslag lyder: "Oslo børs legger til grunn at tilbudsprisen på samme måte som angitt i forarbeidene til dagens lov, skal korrigeres for endringer i kapitalen som utbytte, aksjesplitt, nedsettelse, fondsemisjon mv.” Korrigering skal ifølge Børsen i utgangspunktet ikke foretas for "andre endringer som er vanskelig å beregne selv om det kan påvirke kursen vesentlig som f.eks. emisjon selv om det skulle skje til kraftig over- eller underkurs." ${ }^{102}$ Dette skulle tilsi at etterfølgende kapitalendringer kan få betydning for tilbudsprisen, hvis øvrige formelle rettskilder og reelle hensyn trekker i samme retning som forarbeidene.

\subsubsection{Aksjesplitt og utdelinger}

Slike hensyn gjør seg gjeldende ved en splitting av målselskapets aksjer fra f.eks. en til to og ved utdelinger til eierne i målselskapet, jf. også City Code regel 9.5 pkt. 4 som gjelder utbytte etter at tilbudet er fremsatt. Slik også kommentarene til de svenske takeover-reglene punkt II.10. Begge disse endringene er enkle å beregne, og det vil være lite rimelig om tilbudsprisen ikke kan settes lavere i disse tilfellene.

Et forbehold må etter mitt syn tas for utdelinger, der 1 kr utdelt ikke skulle føre til 1 kr lavere markedsverdi for selskapet. Dette kan være situasjonen for utdelinger f.eks. i selskaper med høy intellektuell kapital. I så fall kan det etter mitt syn bli spørsmål om utdelingen likevel ikke kan føre til en lavere tilbudspris.

\subsubsection{Emisjon til underkurs}

Også en etterfølgende emisjon til underkurs, d.v.s. der tegningskurs er under markedskurs, må muligens føre til en lavere tilbudspris. En emisjon til markedskurs kan som utgangspunkt ikke ha noen betydning, selv om tegningskursen er lavere enn det høyeste vederlag. Spørsmålet er oppe i Eastern Drillingsaken. ${ }^{103}$ Etter at det høyeste vederlag på kr 135 (eventuelt kr 92) ble avtalt, gjennomførte Eastern Drilling en emisjon til tegningskurs kr 90 som tilsvarte det markedet var villig til å betale.

\footnotetext{
100 Spørsmålet har noe begrenset praktisk betydning ved frivillige tilbud, fordi det som regel står i tilbudsdokumentet at utdelinger fra selskapet skal redusere tilbudsprisen tilsvarende, jf. f.eks. tilbudsdokument 10.01.06 (Seadrill/Smedvig).

101 Ot. prp. nr. 29 (1996-1997) s. 79.

102 Ot. prp. nr. 29 (1996-1997) s. 78.

103 Oslo Børs (2006) s. 90 flg.
} 


\subsection{Om kapitalendringer m.v. kan føre til høyere tilbudspris}

Ordlyden står ikke i veien for en høyere tilbudspris. Ifølge forarbeidene skal tilbudsprisen korrigeres for endringer i aksjekapitalen som f.eks. "fondsemisjon." ${ }^{104}$ Dette er ikke innlysende. En fondsemisjon er ikke noe annet enn en reklassifisering av målselskapets kapital i den forstand at kapital overføres fra overkursfond eller frie midler til aksjekapital. Dermed vil en fondsemisjon normalt ikke øke verdien pr. aksje. På den annen side er det åpenbart at minsteprisen er høyere ved en aksjespleis, som f.eks. fra to til én. 


\subsection{Generelt}

\subsubsection{Behovet for en utvidelse av tilbudspliktreglene}

Den som er ute etter kontroll i et selskap går normalt frem ved å erverve aksjer i selskapet. En annen mulighet er å erverve rettigheter og andre interesser knyttet til aksjer. Mest praktisk er inngåelse av total return swap-avtaler (TRS-avtaler), som bl.a. er kjent fra Eastern Drilling saken. En TRS-avtale innebærer i korte trekk at en avtalepart (kjøper av risikoen) erverver den finansielle eksponeringen i en underliggende aksje fra den andre avtaleparten (selger av risikoen) mot en rentebetaling. Kjøperen av risikoen kan oppnå kontroll bl.a. fordi hans relative stemmeandel i målselskapet øker ved at selgeren sikrer seg (hedger) mot kursstigning ved å erverve aksjer i selskapet. Også utstederen av en kjøpsopsjon vil normalt sikre seg ved kjøp av et tilsvarende antall underliggende aksjer, slik at innehaveren vil kunne oppnå kontroll omtrent på samme måte som kjøperen etter en TRS-avtale. ${ }^{105}$

Verken inngåelse av TRS-avtaler eller kjøpsopsjoner, eller det forhold at kjøperens/ innehaverens relative stemmeandel i målselskapet øker, er å anse som et "erverv" som kan utløse tilbudsplikt etter vphl. $\mathbb{6} 6-1(1)$. Og reglene om konsolidering forutsetter at avtalepartene har etablert et (såkalt) forpliktende samarbeid om bruk av eierrettigheter e.l., jf. $\$ 2-5$. For å sikre likebehandling og minoritetsbeskyttelse åpner derfor $\$$ 6-1(4) for at departementet i forskrift kan fastsette regler som pålegger tilbudsplikt ved erverv av rettigheter og andre interesser til aksjer, selv om avtalepartene ikke er konsoliderte. Departementet anmodet Oslo Børs i brev av 29. juni 2007 om å utferdige forslag til slik forskrift, som 1. september 2007 ble sendt ut til høring.

\subsubsection{Virkeområdet etter forskriften}

En regulering der bare TRS-avtaler og kjøpsopsjoner skal kunne utløse tilbudsplikt, vil være svært lett å omgå ved bruk av andre finansielle instrumenter. For å redusere faren for omgåelser foreslås det at forskriften også skal omfatte andre typer rettigheter og interesser knyttet til aksjer, for eksempel terminer og salgsopsjoner. Tilsvarende er lagt til grunn i Storbritannia, jf. City Code regel 9.5. De nærmere reglene om virkeområdet følger av forskriften kap. 6 II $\$ 1$ andre og tredje ledd.

\subsection{Tilbudsprisen}

Her behandles enkelte sider ved reglene om tilbudspris ved erverv av rettigheter og andre interesser knyttet til aksjer, uten pretensjon om fullstendighet. Det må bli lagt til grunn at forskriften blir vedtatt uten endringer. Forskriften inneholder imidlertid ingen særskilt regel om tilbudspris, som dermed må bygge på vphl. \$ 6-10. I høringsnotatet angir Børsen en del retningslinjer for beregning av tilbudsprisen. ${ }^{106}$ Høringsnotatet vil være et forarbeid av en noe spesiell karakter og vekt, fordi det er utarbeidet av Børsen som er et privat allmennaksjeselskap med en viss egeninteresse i de forhold som blir regulert.

\subsubsection{Hvem som må ha avtalt eller betalt vederlaget}

Det er vederlag "tilbyderen" har avtalt eller betalt som kan få betydning for tilbudsprisen, jf. vphl. \$6-10(4) første pktm. Med "tilbyderen” menes som utgangspunkt den som plikter å gi tilbud, det vil normalt si den hvis erverv av rettigheter m.v. utløser tilbudsplikt, jf. forskriften $₫ 1$ første ledd.

Etter forskriften er det ved en TRS-avtale/kjøpsopsjon den som er kjøper/innehaver som er tilbyderen. Men etter vphl. \$6-1(1) kan også selgeren/utstederen komme i en tilbudspliktsituasjon ved et eventuelt

105 Plassen tillater ikke en nærmere redegjørelse for TRS-avtaler, kjøpsopsjoner og andre derivater, eller hvordan erverv av derivater kan føre til kontroll. For mer informasjon, se Oslo Børs (2007) s. 6-8. 
erverv av sikringsaksjer. ${ }^{107}$ Spørsmålet er i så fall om det er kjøperen/ innehaveren eller selgeren/ utstederen som er å anse som tilbyder. Verken verdipapirhandelloven eller forskriften åpner for at begge parter kan være tilbydere og dermed forpliktet til å fremme et tilbud sammen eller hver for seg. Etter mitt syn er det mest rimelig å anse kjøperen/innehaveren som tilbyder, fordi det er disse som normalt har interesse i selskapskontrollen. Men etter verdipapirhandelloven har ikke Børsen noen mulighet til å frita selgeren/utstederen fra tilbudsplikt; forskriften $\mathbb{1}$ sjette ledd gir derimot Børsen en slik mulighet overfor kjøperen/innehaveren. Løsningen må anses usikker.

\subsubsection{Avgrensning av vederlaget som kan få betydning for tilbudsprisen}

Etter vphl. \$ 6-10 fjerde og femte ledd er det bare vederlag for eiendomsrett til aksjer som kan få betydning for tilbudsprisen. Dette følger ikke uttrykkelig av lovens ordlyd, men av sammenhengen med $\$ 6-1(1)$. For forskriftens vedkommende er det sammenhengen med forskriften $\mathbb{1} 1(1)$ som må være relevant, slik at ordlyden nærmest tilsier at det er vederlag for "rettigheter og andre interesser knyttet til aksjer" som kan få betydning for tilbudsprisen. Dermed kan premien ved erverv av kjøpsopsjoner få betydning. Slik også Børsen i høringsnotatet og City Code regel 9.5 note nr. 2. Premien ved salgsopsjoner er for så vidt også betaling for "rettigheter til aksjer." Den kan likevel ikke få betydning for tilbudsprisen, fordi den ikke er betalt av "tilbyderen," jf. vphl. $\$ 6$-10(4) (se punkt 14.2.1). Premien er betalt av innehaveren av opsjonen som har rett til å selge aksjer til tilbyderen (utstederen). Rentebetaling ved TRS-avtaler er betaling for "andre interesser knyttet til aksjer" og kan få betydning for tilbudsprisen.

Innløsningsprisen ved opsjoner er imidlertid $i k k e$ vederlag for "rettigheter til aksjer." For opsjoner med fysisk oppgjør er innløsningsprisen vederlag for eiendomsrett til aksjer, slik at den likevel kan få betydning for tilbudsprisen. For opsjoner med finansielt oppgjør er imidlertid ikke innløsningsprisen vederlag for eiendomsrett til aksjer. Den er bare et utgangspunkt for beregningen ved det finansielle oppgjøret. Det samme gjelder for inngåelsesprisen ved TRS-avtaler. Ifølge høringsnotatet er det imidlertid uttrykkelig uttalt at innløsnings- og inngåelsespris kan få betydning for tilbudsprisen. Slik også City Code regel 9.5 note nr 2. Selv om ordlyden (konteksten) trekker i en annen retning enn høringsnotatet, må likevel høringsnotatet (det vil her si lovgiverviljen) etter mitt syn gå foran slik at innløsningsprisen ved opsjoner med finansielt oppgjør og inngåelsesprisen ved TRS-avtaler kan få betydning for tilbudsprisen etter vphl. $\$$ 6-10 og forskriften.

\subsubsection{Opsjoner. Innløsningspris avtalt ved inngåelse eller innløsning?}

For at et vederlag skal kunne få betydning for tilbudsprisen, må det være "betalt eller avtalt" i vederlagsperioden, jf. vphl. $\mathbb{S}$ 6-10 fjerde og femte ledd. Ordlyden gir ikke noe klart svar på når innløsningsprisen for opsjoner rettslig sett er avtalt (se punkt 6.1.1). Heller ikke høringsnotatet behandler spørsmålet uttrykkelig. Men etter mitt syn forutsetter Børsen at innløsningsprisen er avtalt ved inngåelse av opsjonsavtalen. Dette lar seg utlede av to forhold. For det første, hvis innløsningsprisen først anses avtalt ved innløsning, vil en innføring av regler om tilbudsplikt ved erverv av opsjoner være uten særlig realitet. For da kan nemlig innehaveren (av en opsjon med lang løpetid, typisk warrants) vente med innløsning til etter utløpet av vederlagsperioden, slik at tilbudsprisen må tilsvare opsjonspremien. ${ }^{108}$ Dermed blir prisen uakseptabel lav. For det andre, om verdsettelsen av innløsningsprisen uttaler Børsen: "Ettersom utøvelsestidspunktet kan ligge frem i tid, og gjerne på en bestemt dato, må imidlertid verdien av dette beløpet beregnes (neddiskonteres) per tilbudstidspunktet.” Børsens resonnement forutsetter naturligvis at innløsningsprisen er avtalt ved inngåelsen av opsjonsavtalen, noe som derfor må være konklusjonen her. ${ }^{109}$

107 Med mindre det er grunnlag for å tolke vphl. § 6-1(1) innskrenkende ved erverv av sikringsaksjer.

108 Et forbehold må gjøres dersom vphl. § 6-10(4) annet pktm. om markedskurs kan komme til anvendelse.

109 For øvrig kan det ikke være riktig at diskonteringen skal skje "per tilbudstidspunktet," men per inngåelse av opsjonsavtalen (se punkt 9). 


\subsection{Lovgivning}

2007 Lov om verdipapirhandel (verdipapirhandelloven) av 29. juni nr. 75

2007 Lov om regulerte markeder (børsloven) av 29. juni nr. 74

1997 Lov om verdipapirhandel (verdipapirhandelloven) av 19. juni nr. 79

1997 Lov om allmennaksjeselskaper (allmennaksjeloven) av 13. juni nr. 45

1985 Lov om verdipapirhandel (verdipapirhandelloven) av 14. juni nr. 61

1918 Lov avslutning av avtaler, om fuldmagt og om ugyldige viljeserklæringer (avtaleloven) av 31. mai nr. 4

1915 Lov om rettergangsmåten for tvistemål (tvistemålsloven) av 13. august nr. 6

\subsection{Forarbeider}

Innst. O. nr. 70 (2006-2007) Om lov om verdipapirhandel (verdipapirhandelloven) og lov om regulerte markeder (børsloven)

Ot. prp. nr. 34 (2006-2007) Om lov om verdipapirhandel (verdipapirhandelloven) og lov om regulerte markeder (børsloven)

NOU 2005:17 Om overtakelsestilbud (tilbudsplikt og frivillige tilbud ved oppkjøp av selskaper)

Innst. O. nr. 83 (1996-1997) Om lov om verdipapirhandel

Ot. prp. nr. (1996-1997) Om lov om verdipapirhandel

NOU 1996:2 Verdipapirhandel

Innst. O. nr. 91 (1988-1989) Om lov om endringer i lov av 14. juni 1985 nr. 61 om verdipapirhandel

- tilbudsplikt ved større aksjekjøp

Ot. prp. nr. 53 (1988-1989) Om lov om endringer i lov av 14. juni 1985 nr. 61 om verdipapirhandel

- tilbudsplikt ved større aksjekjøp

NOU 1991:25 Lånefinansierte selskapsoppkjøp

Ot. prp. nr 83 (1986-1987) Om lov om verdipapirbørs

NOU 1985:33 Lov om verdipapirbørs (børsloven)

NOU 1978:42 Verdipapirhandel

\subsection{Vedtak og uttalelser}

Aktiemarknadsnemnden Uttalanden, Stockholm, 2006

Aktiemarknadsnemnden Uttalanden, Stockholm, 2003

Aktiemarknadsnemnden Uttalanden, Stockholm, 2001

Aktiemarknadsnemnden Uttalanden, Stockholm, 1999

Oslo Børs Vedtak og uttalelser, Oslo, 2006

Oslo Børs Vedtak og uttalelser, Oslo, 2005

Oslo Børs Vedtak og uttalelser, Oslo, 2004

Oslo Børs Vedtak og uttalelser, Oslo, 2003

Oslo Børs Vedtak og uttalelser, Oslo, 2002

Oslo Børs Vedtak og uttalelser, Oslo, 2001

Oslo Børs Vedtak og uttalelser, Oslo, 2000

Oslo Børs Vedtak og uttalelser, Oslo, 1999

\subsection{Bøker}

Andenæs, Mads Henry Aksjeselskaper og allmennaksjeselskaper, 2. utg., Oslo, 2006

Bechmann, Tor, Knut Bergo, Jan Bjørnsen m.fl. Verdipapirhandelloven, 1. utg., 2002

Bergo, Knut Børs- og verdipapirrett, Oslo, 2004

Button, Maurice m.fl. A Practitioner's Guide to the City Code on Takeovers and Mergers, City \&

Financial Publishing, 2005/2006

Hov, Jo Avtaleslutning og ugyldighet Kontraktsrett I, 3. utg, Oslo, 2002 


\subsection{Annen litteratur}

Berglihn, Harald Fikk gullkantet ekstrabonus, Dn.no, Oslo, 2002

The City Code on Takeovers and mergers, 2006

Jensen, Tor Chr. Uredelig og grisete, Dagens Næringsliv, Oslo, 2006

Stockholmsbörsens regler rörande offentliga uppköpserbjudanden på aktiemarknaden (takeoverreglene) av 1. juli 2006

Oslo Børs Høringsnotat - Tilbudsplikt ved erverv av rettigheter og andre interesser knyttet til aksjer, Oslo, 2007

Slettan, Are Skeie tjente ekstra på Hydralift-salget, iMarkedet.no, Oslo, 1999 


